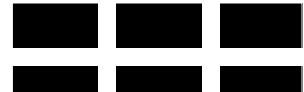 \\ THE WILLIAM DAVIDSON INSTITUTE AT THE UNIVERSITY OF MICHIGAN
}

\section{STRUCTURAL REFORM AND FIRM PROFITABILITY IN DEVELOPING COUNTRIES}

By: Alvaro CUERVO-CAZURRA and Luis Alfonso DAU

William Davidson Institute Working Paper Number 940 July 2008 


\title{
STRUCTURAL REFORM AND FIRM PROFITABILITY IN DEVELOPING COUNTRIES *
}

\author{
Alvaro CUERVO-CAZURRA \\ Sonoco International Business Department, Moore School of Business, U. of South Carolina \\ 1705 College Street, Room 557, Columbia, South Carolina 29208 USA \\ Tel: 1-803-777-0314. Fax: 1-803-777-3609. e-mail: acuervo@moore.sc.edu \\ Luis Alfonso DAU \\ Sonoco International Business Department, Moore School of Business, U. of South Carolina \\ 1705 College Street, Room 553, Columbia, South Carolina 29208 USA \\ Tel: 1-803-777-8294. Fax: 1-803-777-3609. e-mail: luis_dau@moore.sc.edu
}

July 11,2008

We extend agency theory to propose that structural reform positively impacts firm profitability in developing countries because the improvements in external monitoring that accompany structural reform decrease the agency costs faced by firms. However, we also argue that not all firms benefit equally from structural reform because their agency problems are impacted differently. Hence, we propose that structural reform results in higher improvements in profitability for domestic state-owned and domestic private firms than it does for subsidiaries of foreign firms. Results of the analyses of the largest 500 firms in Latin America support the arguments, suggesting that, contrary to the views of many critics of globalization, domestic firms are the main beneficiaries of structural reform in developing countries.

Keywords: agency theory, structural reform, firm profitability, state-owned firms, private firms, subsidiaries of foreign firms, developing countries, globalization

JEL: F23, G34, L33, M21

\footnotetext{
Suggestions by the Special Issue Editor Mauro Guillen, three anonymous reviewers, Joshua Ault, Chei Hwee Chua, Dwight Gardner, Omrane Guedhami, Sophia Jeong, Tatiana Kostova, Chuck Kwok, Eduardo Lora, Gundula Lucke, William I. Mackenzie Jr., Michael Messersmith, Matthew Mitchell, Thomas Moliterno, Kurt Norder, Adrian Pitariu, Robert Ployhart, Scott Ranges, Nelson Rivera, Kendall Roth, Adam Shambaugh, Liang Shao, Andrew Spicer, Annique Un, and Christopher Zorn were very useful for improving the paper. Authors are listed alphabetically. The first author thanks the Center for International Business Education and Research at the University of South Carolina for financial support. The second author thanks the financial support of the University of South Carolina Graduate School. All errors remain ours.
} 
The benefits of structural reform in developing countries are under debate (Bhagwati, 2004; Guillen, 2001; Henisz, Zelner, \& Guillen, 2005; Stiglitz, 2003). In developing countries, structural reform involves a reduction of government intervention in the economy and improvement in national governance (Williamson, 2004). Critics of globalization in general and structural reform in particular argue that the main beneficiaries of structural reform in developing countries are foreign firms, often at the expense of domestic companies (Mander \& Goldsmith, 1996). However, there is little evidence to support or dismiss this view. Evidence on the impact of structural reform on firms is limited and conflicting. Single-country studies find that, in the aftermath of structural reform, firms have improved productivity (e.g., Amann \& Nixson, 1999), strengthened technology (e.g., Katrak, 2002), and increased performance (e.g., Appiah-Adu, 1999). However, other studies do not find improvements in productivity (e.g., Salim, 2003), technology (e.g., Katrak, 2000), or performance (e.g., Okorafo, 1993).

The objective of this paper is to clarify the debate by analyzing how structural reform impacts firm profitability in developing countries. In examining this question, we extend the boundaries of agency theory (Ross, 1973) to argue that the improvements in external monitoring that accompany structural reform lead to a reduction in agency costs, which increases efficiency and, subsequently, improves firm profitability. We also argue that not all firms benefit equally from structural reform because their agency problems are impacted differently. Thus, contrary to the views of critics of globalization, we propose that domestic state-owned and domestic private firms, rather than subsidiaries of foreign firms, are the main beneficiaries of structural reform.

The analyses of the largest 500 firms in Latin America support these arguments. Although the analyses do not test the mediating mechanisms directly, they show that structural reform has a positive impact on firm profitability, and that this positive impact is higher for 
domestic state-owned firms, followed by domestic private firms, and finally, by subsidiaries of foreign firms.

This paper contributes to agency theory by taking a broader view of the theory and discussing a new source of changes in agency costs. Traditionally, agency studies have focused on analyzing the internal mechanisms that solve the agency problems between shareholders and managers (for a review see Becht, Bolton, \& Roell, 2003) and have argued that agency costs vary with changes in ownership (for a review see Berger, Clarke, Cull, Klapper, \& Udell, 2005). Here we take a different route by proposing that agency costs are affected by the institutional environment of the firm and that they diminish with structural reform without the need for changes in ownership. Thus, these ideas help explain the counterintuitive idea that structural reform results in improved profitability for firms in developing countries. We push the theoretical boundary further by arguing not only that firms vary in their agency costs, as traditionally discussed in the literature, but that firms also vary in how their agency costs are affected by structural reform. This idea explains the differences in profitability improvements across firms, with domestic firms rather than subsidiaries of foreign firms being the main beneficiaries of structural reform.

The arguments also contribute to a better understanding of the debate on the impact of globalization on developing country firms (Guillen, 2001; Henisz, Zelner, \& Guillen, 2005). We propose that analyses of the benefits of structural reform need to be more nuanced, studying not only whether structural reform is beneficial but also what types of firms benefit from it.

Although the intellectual lineage of structural reform dates back to Adam Smith (1776) and was kept alive by authors like von Hayek (1944) and Friedman (1962), who proposed that limitations on governments facilitate growth by allowing the ingenuity and entrepreneurial spirit 
of individuals to flourish, this idea had limited influence during most of the $20^{\text {th }}$ century. Governments throughout the world actively controlled the economy. In developed capitalist countries, influenced by the ideas of Keynes (1936), they established restraints on markets. In communist countries, influenced by the ideas of Marx and Engels (1848), they established a centrally planned system and state ownership of factors of production. In developing countries they actively intervened in the economy to speed up industrialization (Sachs \& Warner, 1995). Moreover, in Latin America and in parts of Asia and Africa, influenced by dependency theory (Prebisch, 1950), they implemented import substitution, restricting imports and operations of foreign firms to support the development of indigenous firms (Bruton, 1998).

Governments continued to control the economy until the 1970s, when stagflation forced policymakers to rethink their intervention (Yergin \& Stanislaw, 1998). In the mid-1970s, Chile, under the Pinochet dictatorship, was the first country to implement structural reform, and grew as a result. However, other developing countries did not follow this example because an association was established between structural reform and a totalitarian regime. Nevertheless, the debt crisis of 1982 that spread throughout Latin America forced governments to rethink their position. In the mid-1980s, Bolivia, which was a democracy, undertook structural reform and successfully tackled hyperinflation. It became an example that it was possible to apply structural reform without a strongman. As a result, other countries in Latin America and the developing world implemented similar reforms.

Structural reform - which is often referred to as the Washington Consensus - represents a set of prescribed policies for economic reform to achieve rapid growth in developing countries. Williamson (1990) coined the term Washington Consensus to refer to the desirable policies for reform in Latin America, which were perceived as being dominant in Washington, D.C., where 
the World Bank, the International Monetary Fund, and the U.S. Government are based. Although Williamson's original intent was to persuade policymakers that Latin America was indeed engaged in serious reform (Williamson, 2000), the term came to be used as a prescription for development and as a way to solve the ailments of developing countries in general (Williamson, 2004). The original reforms prescribed the reduction of government intervention in the economy through reforms such as deregulation, liberalization, and privatization, and were later revised to also include improvements in national governance (Rodrik, 2006; Williamson, 2004).

Structural reform helped developing countries achieve stability, but by the late 1990s doubts about the benefits of structural reform began to emerge, particularly in Latin America. Many countries had started with rapid reforms in multiple areas to address the economic malaise of the 1980s, using a so-called "shock therapy" (Sachs \& Warner, 1995). These reforms resulted in countries regaining macroeconomic stability and economic growth, which benefited the population (Kuzynski \& Williamson, 2003). For example, between 1990 and 2006, the proportion of people living in poverty as a percentage of the total population in Latin America diminished from $48.3 \%$ to $36.5 \%$ (ECLAC, 2007). However, skeptics point out that growth has been uneven and limited, and they doubt the true impact of structural reforms on growth (Fraga, 2004; Katz, 2004; Escaith \& Morley, 2000). Some countries even experienced deep but brief economic crises, such as Mexico in 1995, Brazil in 1999, and Argentina in 2001. Defenders of structural reform counter by arguing that reforms were not always consistently implemented. Some countries implemented reforms rapidly while others took a gradual approach; certain countries implemented most of the reforms while others took a more piecemeal approach. These differences have resulted in different degrees of progress towards growth and development (Kuzcynski \& Williamson, 2003). 
There has been opposition to the reforms. Some policymakers deemed it beneficial for them to blame the Washington Consensus for the ailments of the country rather than accept responsibility for the incorrect application of its prescriptions (Lora, Panizza, \& Quispe-Agnoli, 2004; Ocampo, 2004). Some governments even backtracked from reforms for ideological or practical reasons. For example, Argentina imposed price controls in the early 2000s, and Venezuela nationalized petroleum fields in the mid-2000s. Moreover, although there has been managerial support for the reforms, some firms pressured the government to slow down or reverse their implementation. A Costa Rican agriculture businessman summarized the view that the reforms were to stay: "Today we accept the commercial opening and the need to be more competitive as part of a global trend that, although some in our countries are trying to delay, cannot be stopped" (Colburn \& Sanchez, 2000: 59). However, firms with tight connections to the government suffer from the severance of these connections as a result of the reforms (Fisman, 2001; Krueger, 1974) and will adopt political strategies to protect themselves from additional competition (Bonardi, 2004; Bonardi, Hillman, \& Keim, 2005). A Guatemalan civil servant explained the opposition to reform: "Few can imagine the strength with which the private sector pressures the Central Bank, the government's economic team, and even the President so that they reinstate or do not remove the protection against the arrival of new competition from abroad" (Colburn \& Sanchez, 2000: 62).

This discussion indicates that the debate concerning the benefits of structural reform appears to require more nuanced analyses, especially at the firm level. For example, structural reform appears to have induced firms to improve productivity (Eslava, Haltiwanger, Kugler, \& Kugler, 2004), to become multinational firms (Cuervo-Cazurra, 2007, 2008; Guillen, 2005), and to have facilitated investments, but weak institutions limited the benefits from such investments 
(Moguillansky \& Bielschowsky 2000). Therefore, we contribute to these studies by analyzing how and which types of firms benefit from structural reform.

\section{Theoretical Bases for Analyzing Structural Reform and Firm Profitability}

Agency theory focuses on the problems of managing collaboration among economic actors (Eisenhardt, 1989). The theory can be applied to any relationship between two parties where one of these, the agent, acts on behalf of or as a representative of the other, the principal, in making a decision (Ross, 1973: 134). Agency problems emerge from differences in objectives and attitudes towards risk between the principal and agent (Ross, 1973). Rational self-interested behavior, information asymmetry, imperfect monitoring, bounded rationality, and opportunism give rise to agency costs in the relationship (Eisenhardt, 1989; Jensen \& Meckling, 1976).

Although most researchers associate agency theory with the study of relationships between owners and managers (for reviews see Becht, Bolton, \& Roell, 2003, and Daily, Dalton \& Cannella, 2003), the theory can be used to explain other relationships where principals require the assistance of agents (Ross, 1973; for a review see Holmstrom \& Tirole, 1989). These include relationships between bondholders, shareholders, and managers (e.g., Harris \& Raviv, 1991); superiors and subordinates (for reviews see Milgrom \& Roberts, 1992, and Predergast, 1999); a multinational enterprise (MNE) and its subsidiaries (e.g., Roth \& O’Donnell, 1996); the firm and its distribution channels (e.g., Lassar \& Kerr, 1996); the firm and its suppliers (e.g., Camuffo, Furlan, \& Rettore, 2007); the firm and its alliance partners (e.g., Reuer \& Ragozzino, 2006); and the firm and its acquisitions (e.g., Wright, Kroll, Lado, \& van Ness, 2002). The theory has even been applied to analyze relationships among interest groups, agencies, and the government (e.g., Spiller, 1990), and entire economic systems (e.g., Aoki, 1990). 
Most analyses of changes in agency costs have focused on those arising from changes in ownership (for a review see Berger et al., 2005), such as when the firm changes from state to private ownership (e.g., Dharwadkar, George, \& Brandes, 2000), or when it changes from being quoted in the stock market to being privately held (e.g., Phan \& Hill, 1995).

We extend the theory to argue that agency costs may also vary with changes in the institutional environment, structural reform in particular. North (1990: 3) defines institutions as "the rules of the game in a society ... the humanly devised constraints that shape human interaction” (p. 3). Structural reform represents an important type of institutional change by which the laws and regulations of a country are altered to improve the functioning of the market (Williamson, 1990, 2004). Thus, as we discuss in more detail below, structural reform improves monitoring of managers and reduces agency costs, helping firms improve profitability. In this manner, agency costs may change without the need to alter the ownership of the firm.

The model we describe below is subject to some boundary conditions. First, the model examines the general impact of the overall structural reform on firm profitability. Structural reform has multiple dimensions that complement and reinforce each other's influence because they are part of a system (Milgrom \& Roberts, 1990). Thus, the arguments presented below emerge from the interaction among the dimensions. This approach complements other research that has focused on the impact of individual dimensions of structural reform on firms (e.g. Hay, 2001; Kim \& Prescott, 2005; Megginson \& Netter, 2001; Mitton, 2006). Second, the model explains the behavior of firms in developing capitalist countries, where state-owned, private, and foreign firms coexisted before and throughout the implementation of structural reform. This complements studies of firms in transition economies, where private firms did not exist before the transition, and hence are likely to behave differently (for reviews see Peng \& Heath, 1996, 
and Meyer, 2001). Third, the model explains the behavior of firms in developing countries, where structural reform involves both the reduction of government intervention in the economy and improvements in national governance (Williamson, 2004). This complements studies of firms in developed countries, which have well established institutions and where structural reform consists primarily of economic deregulation (for a review see Winston, 1993). Fourth, the model applies to large firms which can more easily choose alternative strategies and survive structural reform (Khanna \& Palepu, 2000). Small firms have fewer strategic choices and face more serious survival challenges (Mata \& Portugal, 2004). Fifth, the model studies the impact of structural reform on the agency costs of three types of firms based on their majority ownership: domestic state-owned, domestic private, and subsidiaries of foreign firms. We do not study how agency costs vary with changes in ownership because this has been widely studied in previous literature. Hence, we do not include privatized firms as a separate category because they represents a change from one of our three firm types (i.e., domestic state firms) to one of the other two (i.e., domestic private firms or subsidiaries of foreign firms). As such, based on our categorization, privatized firms are not a type of firm, but a change from one of the types to the others. Its change in agency costs and profitability have been widely studied (e.g. Boubakri, Cosset, \& Guedhami, 2005; D'Souza, Megginson, \& Nash, 2005; for reviews see Cuervo \& Villalonga, 2000, and Megginson \& Netter, 2001). Nevertheless, because of the relevance of privatization as part of structural reform we control for its influence in the analysis.

\section{The Impact of Structural Reform on Firm Profitability}

We argue that structural reform tends to have a positive impact on firm profitability for firms in general. Although most analyses of agency theory focus on internal mechanisms that reduce agency costs in the relationship between shareholders and managers, such as contract 
design, incentive systems, or internal controls (for reviews see Holmstrom \& Tirole, 1989; Prendergast, 1999), the theory also considers external mechanisms that help reduce agency costs: labor, capital, and product markets (Fama, 1980; Fama \& Jensen, 1983). Unfortunately, the role of these external monitoring mechanisms in monitoring managers has tended to be overlooked, with the exception of capital markets (Jensen, 1993; Walsh \& Seward, 1990). We study these external mechanisms, which form part of the country's institutions, and discuss how structural reform, by improving the functioning of these markets, helps not only reduce the agency costs of monitoring and restraining managerial misbehavior, resulting in improved efficiency, but also provide additional incentives, resulting in higher productivity. As a result, firms experience increased profitability.

The market for managers acts as a control on managerial misbehavior (Fama, 1980). Managers face competition not only from alternative managerial teams that may replace the managers if profitability is not high, but also from managers in the firm who may replace their superiors if the firm is not profitable (Fama, 1980). Structural reform lifts the strict limitations on the hiring and firing of personnel that previously had minimized the pressure of the labor market on managers. As firing and hiring becomes easier, a more competitive market for managers emerges, with talent becoming more mobile, putting pressure on and helping firms improve their managerial teams. For example, Juan Navarro, CEO of Exxel, an Argentinean private equity firm created in 1992, discussed how the main source of value creation in Supermercados Norte, an Argentinean supermarket chain it acquired in 1996 was "the experience of [Norte's CEO Alberto] Guil ('the most successful manager of supermarkets and now he is with us') and a group of individuals [Exxel] with solid experience in other areas, which brings very interesting intellectual and business complementarities" (Correa, 1996: 6). Another example of the 
improvement in managerial teams is offered by Guillermo Gotelli, Vice President of the Argentinean shoe and textile firm Alpargatas, who commented in a personal interview on May 15, 1997, that "there is a now professionalization of management; executives that are professionals. Top managers can no longer be selected based on their last names". One reason for the professionalization of management teams in family-owned firms was given by Oscar Vicente, Vice President of the Argentinean conglomerate Perez Companc, who jokingly indicated that "firms are managed by those who know more and are mismanaged by friends and relatives" (Estenssoro, 1992: 29). These managerial markets pressure incumbent managers to curb their opportunism and improve efficiency and profitability, or face being supplanted by alternative managers (Coughlan \& Schmidt, 1985), particularly in state-owned or partiallyprivatized firms (Cuervo \& Villalonga, 2000; Garcia-Canal \& Guillen, 2008; Roland \& Sekkat, 2000). Additionally, the liberalization of labor markets helps provide incentive for productivity as there differential pay among managers emerges (Gersbach \& Schmutzler, 2007). Firms are able to tie better the objectives of the manager to higher productivity and profitability through incentives (e.g. Jensen \& Murphy, 1990, for a review see Barkema \& Gomez-Mejia, 1998). Thus, in the restructuring of a white goods Argentinean firm done by the consultant Rodolfo Biasca "the first thing to do was to decapitate the firm: the management team was replaced, personnel was reduced by $20 \%$, and then the remuneration system was replaced by one that links the level of salaries to profitability" (Chemi \& Figueroa, 1995).

Capital markets act as a monitor of mismanaged firms, primarily of publicly traded firms, in some cases substituting for imperfections of internal controls (Fama, 1980; Fama \& Jensen, 1983; Jensen, 1993). Structural reform facilitates the development of capital markets. The liberalization of capital markets, the privatization of firms, and the reform of pension systems 
result in the growth and deepening of capital markets (Kuczynski, 2003; Galindo, Micco, \& Panizza, 2006). These deeper capital markets increase scrutiny over managers and limit their opportunism by better pricing their misbehavior in the costs of capital. Thus, partial privatization in Indian state-owned firms results in higher profitability, productivity, and investment as a result of the monitoring and rewarding functions of capital markets (Gupta, 2005). Firms that show low profitability face higher costs of debt and lower equity valuations, which may eventually lead to a takeover by other firms (Jensen, 1993). For example, in Argentina, structural reform and the development of capital markets led to the emergence of private equity funds, which did not exist before, increasing the number of takeovers. "Recent years witnessed a new phenomenon: the rapid change of owners in a number of firms and the emergence of operators that make money in these changes ... In BISA, the same as in CEI, Exxel and AVP, one of the characteristics is the use to independent managerial groups that manage each of the firms separately. In all cases the main objective is to increase the profitability of the firms to later sell them." (Borensten \& D’Atri, 1996: 8). Juan Navarro, CEO of Exxel, explained his firm' strategy in the following terms: "the business is to make the firms better, more valuable. We do not sell them if selling is not a good business. Before this, we seek that the firms have adequate funding, that they are publicly quoted ... In 1990 we perceived that there was room in the market for this type of approach, especially after the changes that had started in Argentina which indicated a long-term trend; institutional investors observed Argentina with interest, and this opened the possibility of funding our firm ... Since in every firm there is risk capital, all have to be profitable ... There is no subsidy from one firm to another; each one has to maximize its business plan." (Correa, 1996: 6). At the same time, the reform of capital markets gives rise to more powerful regulatory agencies that scrutinize the behavior of firms and limit managerial misbehavior (Kuczynski, 
2003). Additionally, the reform of regulations that protect investors reduces managerial misbehavior (Djankov et al., 2002; La Porta et al., 1998). As the consultant Peter Davis discussed in 1994, "now in the Argentinean Stock Exchange they are trying to define with more precision what the rights of shareholders are" (Rimuli, 1994: 152).

The product market acts as a control mechanism on managerial misbehavior of last resort (Hart, 1983). Structural reform lifts government restrictions and exclusions on new entrants, increasing competition (Blomstrom, 1986; Blomstrom \& Kokko, 1998). Product markets become more competitive because restrictions on imports and on foreign investors are lifted, as well as regulatory constraints in the industry. This provides incentives to firms to improve their productivity to face both new foreign and domestic competitors. "At the moment, explains Luis Gotelli, director of Alpargatas, we are not thinking about building new plants or expanding, but we have to focus our efforts in increasing global productivity, make products of international quality, develop new local and foreign customers, and improve the quality of managers and human resources. We are conscious that the country is moving towards higher competitiveness." (Mercado, 1991: 19) As competition increases, managers are forced to seek improvements in efficiency, because firms that do not achieve minimum levels of efficiency disappear (Demsetz, 1973). A Guatemalan businessman illustrates this idea: "If I had to define the manner to compete in the market with one word, this would be aggressiveness. In the international market there is no love or social conscience; there are profits, period" (Colburn \& Sanchez, 2000: 59). Firms reorganize operations and reallocate effort from low to high efficiency initiatives (Eslava et al., 2004), which improve profitability. This is illustrated by the experience of a Salvadorian poultry farmer: "Here, one can be successful when one is more efficient than the rest, not when one has more natural resources. In our company, this has meant improving the genetics, nutrition, health 
standards, management, and information, not only inside the firm, but also with our shareholders, suppliers, and customers. As a result, in five years we have increased the productivity of hens from 150 eggs per year to 320” (Colburn \& Sanchez, 2000: 108).

In sum, structural reform improves the external monitoring by managerial, capital, and product markets. This, in turn, reduces agency costs by limiting managerial misbehavior and opportunism that result in improvements in efficiency, and provide incentives for increased productivity, leading to increased firm profitability. Although we do not directly analyze the mediating mechanisms, we can formally propose that:

Hypothesis 1: Structural reform in developing countries has a positive impact on firm profitability.

\section{Firm Type and the Impact of Structural Reform on Firm Profitability}

We also propose that the positive impact of structural reform on firm profitability varies across three types of firms: domestic state-owned, domestic private, and subsidiaries of foreign firms. Traditionally, agency theory argues that firms vary in their profitability level because they have different agency problems and costs, and that these costs change with ownership changes (e.g. Boardman \& Vining, 1989; Dewenter \& Malatesta, 2001; for reviews see Becht, Bolton, \& Roell, 2003, and Berger et al., 2005). We extend agency theory by proposing that agency costs diminish with structural reform without the need for changes in ownership. Since each firm type

faces specific agency problems, structural reform impacts them differently. Thus, firms not only differ in their agency costs and level of profitability, but also in how structural reform affects their agency costs and thus their improvement in profitability.

Domestic State-Owned Firms. State-owned firms suffer from substantial agency problems of separation of ownership and control (for reviews see Lawson, 1994, and Shleifer \& 
Vishny, 1994) because they are nominally owned by the citizenry (principals), but are controlled by politicians or by managers appointed by politicians (agents). Owners - citizens - have no corporate governance mechanisms to influence how managers - politicians or political appointees - run these firms. Citizens cannot request to have representatives on the board of directors or challenge management in shareholder meetings because they do not have access to shares; shares are held in trusts and controlled by politicians. Even when a state-owned firm is quoted in the stock market, politicians still control it through majority shareholdings. Additionally, state-owned firms are subject to competing pressures from interest groups, such as unions and local communities who have a nominal claim over state-owned firms, which lead to lobbying for transfers (Cigler \& Loomis, 2006; Dixit, Grossman, \& Helpman, 1997; Olson, 1971). As a result, many state-owned firms are charged with making decisions that have little business value but high political benefits, such as sustaining employment or promoting the development of a region (Vickers \& Yarrow, 1988; Zahra, Ireland, Gutierrez \& Hitt, 2000), which reduce their profitability. Their managers have little interest in restructuring, expanding or altering strategy radically because they have to pursue political as well as financial goals (Cuervo \& Villalonga, 2000; Zhara, Ireland, Gutiérrez, \& Hitt, 2000). Additionally, the ultimate control by product markets is also ineffectual. State-owned firms do not go bankrupt even when they are unprofitable because the politicians who run them protect them from competition (Shleifer \& Vishny, 1994) and use their control of the general budget or state-owned banks to provide funds and a soft budget to the firms (Kornai, 1990).

Structural reform is likely to result in large improvements in the profitability of domestic state-owned firms because of the large reductions in agency costs that state-owned firms 
experience with structural reform ${ }^{1}$. As a result of structural reform, politicians are constrained in the way they manage not only the overall government, but also state-owned firms (Laffont \& Tirole, 1990; Williamson, 2004). Politicians no longer can use state-owned firms for their own personal benefit because their use of state-owned assets is subject to higher scrutiny. As Raul Campos, executive manager for investor relations of Petrobras, states: "the mission and shareholder structure of Petrobras prevents the government from using the firm as a cash cow" (Schneyer, 2005: 67). Additionally, structural reform leads to a change of managers and the introduction of incentive mechanisms that induce managers of state-owned firms to focus on improving efficiency, leading to increased profitability, while the threat of privatization acts as an additional incentive (Vogelsang, 1990). Managers of state-owned firms are empowered to make more decisions that are useful to the competitiveness of the firms and fewer decisions that are merely politically motivated. As Fernando Bracco, President of the Uruguayan state-owned telecommunications firm Antel, indicated: "Today, the discussion is not on whether Antel is state-owned or private; the topic is whether the firm has the necessary tools to operate in a new environment" (Stok, 2000: 41).

Domestic Private Firms ${ }^{2}$. Domestic private firms in developing countries tend to be controlled by the founding family and have few or no shares quoted in the stock market (Booth, Aivazian, Demirguc-Kunt, \& Maksimovic, 2001; La Porta, Lopez-de-Silanes, \& Shleifer, 1999). As a result, domestic private firms suffer fewer agency problems of separation of ownership and

1 We do not discuss how privatization reduces agency costs and improves profitability (e.g. Boubakri, Cosset, \& Guedhami, 2005; D'Souza, Megginson, \& Nash, 2005); we control for this in the analysis. Moreover, privatization not only results in higher profitability, but also in different behavior (Garcia-Canal \& Guillen, 2008).

Despite the perception that developing-country firms are less competitive than others, the capabilities of private firms are appropriate for the conditions of developing countries and help them operate profitably (Lall, 1983). Additionally, they are adept at managing in challenging institutional conditions, which further supports their profitability (Ghemawat \& Khanna, 1998; Guillen, 2000; Khanna \& Palepu, 1997) and helps them to become multinational firms (Cuervo-Cazurra, 2007, 2008; Cuervo-Cazurra and Genc, 2008). 
control than other types of firms, resulting in high profitability. The family (principals) owns the firm and either runs it, or has professional managers (agents) running it under tight control (Claessens, Djankov, \& Lang, 2000). The majority shareholding enables the family to exercise control over management effectively to prevent their misbehavior (Shleifer \& Vishny, 1997). Moreover, since much of the wealth of the family is tied to the firm, family owners have an incentive to make decisions, or to have managers make decisions, that are profitabilityenhancing. However, private firms with concentrated ownership suffer from a different agency problem: the problem that exists between the controlling family and minority shareholders (Shleifer \& Vishny, 1997). The controlling family may induce the firm to act in a manner that benefits the family at the expense of minority shareholders (Morck, Wolfenzon, \& Yeung, 2003). However, such expropriation is likely to be limited because misbehavior by the family has direct wealth repercussions (Anderson \& Reeb, 2003).

Structural reform increases the profitability of domestic private firms, but not as much as that of domestic state-owned firms, because of their more limited relative improvements in agency costs. The strengthening of national governance mechanisms that accompany structural reform (Williamson 2004) does not measurably alter the owner-manager agency problems because these are already low. Instead, they help ameliorate the agency costs between the controlling family and minority shareholders. Improvements in governance result in better protection of minority shareholders and boards of directors that are accountable to all shareholders, not only to majority shareholders (La Porta et al., 1999; Khanna, Kogan, \& Palepu, 2006). Managers can no longer take solely the objectives of blockholders into account at the expense of minority shareholders. Instead, they increasingly need to focus on improving their firm's profitability for the benefit of all shareholders. This is illustrated by Luis Echarte, CFO of 
TV Azteca, the second-largest TV operator in Mexico, who commented on the president of the group, Ricardo Salinas: "Ricardo is a smart man: he realized the importance of having an independent board. First, because the members bring a diversity of ideas, instead of having his friends on the board agreeing with everything he says. If he cannot convince the board that what he wants is a good idea, then certainly he will not be able to convince investors either" (Fretz, 2000: 57).

Subsidiaries of Foreign Firms. As a result of belonging to a foreign parent, subsidiaries of foreign firms suffer from an employment agency problem (Milgrom \& Roberts, 1992), in particular the agency problem of multiunit firms (Scharfstein \& Stein, 2000), rather than the traditional shareholder-manager problem that other firms suffer. There is a divergence of objectives between managers at headquarters (principals) and subsidiary managers (agents) (Roth \& O’Donnell, 1996) that limits profitability ${ }^{3}$. This divergence of objectives is compounded by the global integration-local responsiveness challenge of the multinational enterprise (MNE) (Doz \& Prahalad, 1984) that results in a struggle among managers (Andersson, Forsgren, \& Holm, 2007; Mudambi \& Navarra, 2004). Managers at headquarters are interested in operating subsidiaries in multiple countries to achieve the benefits of global integration that facilitate the success of the MNE as a whole, thus helping advance their own careers. In contrast, subsidiary managers are interested in managing the subsidiary in the country to achieve the benefits of local responsiveness and help it succeed, advancing their own careers as a result. This divergence of objectives generates a conflict in the mandate or strategy of the subsidiary that leads to inefficiencies and reduces profitability (for a review of mandates see Birkinshaw, 2001). This

\footnotetext{
3 Although subsidiaries of foreign firms have multiple advantages (for reviews see Tallman \& Yip, 200, and Cuervo-Cazurra and Un, 2004), they still face challenges when operating abroad that result in lower performance than domestic firms (Zaheer, 1995, for a review see Cuervo-Cazurra, Maloney, \& Manrakhan, 2007).
} 
idea is illustrated by Professor Franco Parisi of the University of Chile, who, commenting on the Spanish energy firm Endesa's acquisition of the Chilean firm Enersys, indicated that Endesa "is going to centralize purchasing and financing decisions and transfer the earnings to headquarters. This is logical and not a sin. They paid for the right to do so" (Vera \& Stok, 2000: 53). Additionally, subsidiary managers may waste resources promoting their advancement, obtaining funds for investment in projects that may be of little business value for the subsidiary but of high personal value, thus reducing profitability (Scharfstein \& Stein, 2000).

Structural reform helps subsidiaries of foreign firms improve their profitability, but not as much as domestic state-owned or private firms because the agency problems faced by the subsidiaries of foreign firms are little impacted by structural reform. Improvements in corporate governance have little impact on the relationship between managers at headquarters and subsidiary managers; they still face divergent interests in the employment relationship. Moreover, structural reform may even heighten the agency problems between headquarters and subsidiary managers. Structural reform changes the conditions of operation. Managers in headquarters may not understand how structural reform is affecting the subsidiary and thus may not allow it to adapt to the new environmental conditions as much as managers in the subsidiary believe is necessary. Thus, despite structural reform resulting in the creation of policies that favor foreign investment (Chung \& Beamish, 2005), the subsidiary may have an inappropriate mandate for the new environmental conditions, thus showing limited profitability improvements.

In sum, based on the discussion of these three types of firms and on how structural reform affects their specific agency costs differently, we propose a relative ranking of the improvement that structural reform has on firm profitability. Specifically, we argue that: 
Hypothesis 2. The type of firm moderates the relationship between structural reform and firm profitability, such that the positive impact is greatest for domestic state-owned firms, followed by domestic private firms, and finally by subsidiaries of foreign firms.

\section{RESEARCH DESIGN}

We test the hypotheses on a panel of the largest firms in Latin America from 1989-2005. We choose firms in Latin America because countries in this region serve as a natural laboratory to analyze the influence of structural reform on firm profitability in developing countries. Latin American countries followed an import substitution model of development until the 1980s, and undertook structural reform in the 1980s and 1990s (Kuczynski \& Williamson, 2003; Skidmore \& Smith, 2005), resulting in commonalities in the behavior of foreign and domestic firms (Grosse, 2001). We study the period 1989-2005, which covers the bulk of the transformation of the countries and firms in response to structural reform. The period shows variance in the level of structural reform across countries, which enables one to test the hypotheses adequately.

Additionally, studying firms in Latin America contributes to the literature because this region has been understudied. The reviews of strategy research in emerging economies by Hoskisson, Eden, Lau, and Wright (2000) and by Wright, Filatotchev, Hoskisson, and Peng (2005) show that most studies focus on firms from Asia or from transition economies. A review of the two leading international management journals, Journal of International Business Studies and Management International Review, shows that less than $6 \%$ of the articles mention Latin America (Elahee \& Vaidya, 2001). 
The database consists of the 500 largest firms in Latin America that AmericaEconomía magazine has compiled annually since $1989^{4}$. The database is one of the most complete sources of data on firms in Latin America and has been used in other research, such as analyses of firm internationalization (Thomas, Eden, Hitt, \& Miller, 2007) and the annual analyses of foreign direct investment (FDI) in Latin America published by the United Nations (ECLAC, various years). Unlike other rankings, such as Fortune 500 in the U.S., the list includes publicly-traded and private firms. The inclusion of private firms facilitates the generalization of the results to all firms rather than only to publicly-traded firms, which are a minority in developing countries (Booth et al., 2001), but limits obtaining additional data because private firms have lower disclosure requirements. As a result, we are unable to directly measure and test the theoretical mechanisms that link structural reform to firm profitability. The database lists the largest firms in Latin America by sales and provides basic accounting data on net profits, equity, assets, employees, exports, industry, and country of origin, an indicator specifying whether firms are quoted in the stock market, and a categorization of firms by majority ownership into stateowned, private, or foreign.

Although the use of accounting data in multiple countries creates challenges (Megginson and Netter, 2001), it is not uncommon in the literature (e.g. Boubakri, Cosset, \& Guedhami, 2005; D'Souza \& Megginson, 1999, D’Souza, Megginson, \& Nash, 2005; Herrera \& Lora, 2005; Megginson, Nash, \& Randenborgh, 1994; Micco, Panizza, \& Yanez, 2007). Three challenges are worth noting ${ }^{5}$. First, countries may have different reporting requirements that may limit the comparability of measures across countries. Second, there may be changes in

4 Countries that have firms large enough to appear in the AmericaEconomía database are: Argentina, Barbados, Bolivia, Brazil, Costa Rica, Chile, Colombia, Ecuador, El Salvador, Guatemala, Honduras, Jamaica, Mexico, Panama, Peru, Trinidad and Tobago, Uruguay, and Venezuela. The final sample excludes firms from Barbados, Jamaica, and Trinidad and Tobago because we lack a measure of structural reform for these countries.

$5 \quad$ We thank an anonymous reviewer for suggesting these possibilities. 
accounting or reporting standards, for example because of structural reform, that may limit the comparability of measures across time. Third, the disciplining of governments with structural reform may reduce their ability to appropriate wealth and thus may result in more accurate reporting of earnings. We think that some of the problems inherent in multi-country studies are reduced in the present study. First, AmericaEconomía gathers data from the firms and external data providers to ensure its reliability and comparability across countries. Second, we study the largest firms in the region, which are likely to have more complete and accurate data reported. Third, we focus on basic variables such as sales and net income that represent the lowest denominator accounting variables and thus are less subject to problems (Megginson, Nash, \& Randenborgh, 1994). Fourth, changes in reporting standards or governmental behavior may result in more accurate reporting, but such accuracy will likely to apply not only the reporting of profits but also the reporting of losses and balance items. Moreover, using ratios absorbs this increased accuracy across years. Fifth, we control for year and country in the analyses, thus taking into account differences that may exist in the measures across time and location.

\section{Variables and Measures}

Table 1 summarizes the variables and measures used in the analysis. The dependent variable is profitability. We measure it using return on sales (ROS), a measure of profitability commonly used in the literature (e.g. Geringer, Tallman, \& Olsen, 2000; Palepu, 1985). In addition, one important justification for using ROS is that the ratio includes two flow measures which, compared to ROA, tend to be less influenced by inflation and accounting standards (Megginson et al., 1994; Boubakri et al., 2005). 
TABLE 1

Variables, measures, and sources of data

\begin{tabular}{|c|c|c|c|}
\hline Variable & Measure & Value & Source \\
\hline Profitability & $\begin{array}{l}\text { Return on sales, or earnings before taxes, interest and } \\
\text { depreciation divided by revenue }\end{array}$ & Continuous & $\begin{array}{l}\text { Computed using data from } \\
\text { AmericaEconomía (various years) }\end{array}$ \\
\hline Structural reform & $\begin{array}{l}\text { Indicator of the level of structural reform undertaken } \\
\text { in the country }\end{array}$ & 0 to 100 & $\begin{array}{l}\text { Obtained from Sahay and Goyal } \\
(2006)\end{array}$ \\
\hline Foreign firm & $\begin{array}{l}\text { Indicator that the majority of the firm's capital is } \\
\text { owned by investors from another country }\end{array}$ & 1 or 0 & $\begin{array}{l}\text { Computed using data from } \\
\text { AmericaEconomía (various years) }\end{array}$ \\
\hline $\begin{array}{l}\text { Domestic private } \\
\text { firm }\end{array}$ & $\begin{array}{l}\text { Indicator that the majority of the firm's capital is } \\
\text { owned by private investors in the home country }\end{array}$ & 1 or 0 & $\begin{array}{l}\text { Computed using data from } \\
\text { AmericaEconomía (various years) }\end{array}$ \\
\hline $\begin{array}{l}\text { Domestic state- } \\
\text { owned firm }\end{array}$ & $\begin{array}{l}\text { Indicator that the majority of the firm's capital is } \\
\text { owned by the state in the home country }\end{array}$ & 1 or 0 & $\begin{array}{l}\text { Computed using data from } \\
\text { AmericaEconomía (various years) }\end{array}$ \\
\hline Privatized firm & $\begin{array}{l}\text { Indicator that the firm changed majority ownership } \\
\text { from state to private or foreign firm }\end{array}$ & 1 or 0 & $\begin{array}{l}\text { Computed using data from } \\
\text { AmericaEconomía (various years) }\end{array}$ \\
\hline Business group & $\begin{array}{l}\text { Indicator that the firm belongs to a Latin-American } \\
\text { business group }\end{array}$ & 1 or 0 & $\begin{array}{l}\text { Computed using data from } \\
\text { AmericaEconomía (various years) }\end{array}$ \\
\hline Publicly-traded & $\begin{array}{l}\text { Indicators that the firm has shares quoted in the stock } \\
\text { exchange }\end{array}$ & 1 or 0 & $\begin{array}{l}\text { Computed using data from } \\
\text { AmericaEconomía (various years) }\end{array}$ \\
\hline Sales & Total sales in millions of US\$ & Positive & $\begin{array}{l}\text { Computed using data from } \\
\text { AmericaEconomía (various years) }\end{array}$ \\
\hline GDP per capita & $\begin{array}{l}\text { Gross domestic product in thousands of US\$ divided } \\
\text { by total population }\end{array}$ & Positive & $\begin{array}{l}\text { Computed using data from World } \\
\text { Development Indicators, World } \\
\text { Bank (2008) }\end{array}$ \\
\hline Openness & $\begin{array}{l}\text { Exports and imports of goods and services divided by } \\
\text { gross domestic product multiplied by } 100\end{array}$ & Positive & $\begin{array}{l}\text { Computed using data from World } \\
\text { Development Indicators, World } \\
\text { Bank (2008) }\end{array}$ \\
\hline GDP growth & $\begin{array}{l}\text { Difference in gross domestic product for the year and } \\
\text { the previous year divided by gross domestic product } \\
\text { in the previous year }\end{array}$ & Continuous & $\begin{array}{l}\text { Computed using data from World } \\
\text { Development Indicators, World } \\
\text { Bank (2008) }\end{array}$ \\
\hline Industry & $\begin{array}{l}\text { Indicator of the industry of the firm at the 2-digit } \\
\text { NAICS level (17 industries) }\end{array}$ & 1 or 0 & $\begin{array}{l}\text { Computed using data from } \\
\text { AmericaEconomía (various years) }\end{array}$ \\
\hline Country & $\begin{array}{l}\text { Indicator of the country of origin of the firm ( } 15 \\
\text { countries) }\end{array}$ & 1 or 0 & $\begin{array}{l}\text { Computed using data from } \\
\text { AmericaEconomía (various years) }\end{array}$ \\
\hline Year & Indicator of the year of analysis (17 years) & 1 or 0 & $\begin{array}{l}\text { Computed using data from } \\
\text { AmericaEconomía (various years) }\end{array}$ \\
\hline
\end{tabular}

The main independent variable of interest is structural reform. We measure it with the International Monetary Fund's structural reform index (SRI) compiled by Sahay \& Goyal (2006) which covers the period $1970-2005^{6}$. It captures economic liberalization and improvements in

$6 \quad$ Several independent indices measure structural reform or related concepts. Morley, Machado, \& Pettinato (1999), from the Economic Commission for Latin America and the Caribbean of the United Nations, developed a structural reform index for Latin America covering the years 1970-1995. Lora (2001), from the Inter-American Development Bank, created a structural reform index for Latin America for the period 1985-1999. Gwartney, Lawson, and Easterly (2007) compiled the Fraser Institute's measure of Economic Freedom of the World. It is available at five year intervals for 1970-2000 and annually thereafter for all countries. Kane, Holmes, and O'Grady (2007) created the Heritage Foundation's Index of Economic Freedom. It is available for the period 1995-2005 for all countries. Sahay \& Goyal (2006) combined the indexes by Morley et al. (1999) and Kane et al. (2007) to develop an index that spans the period 1970-2005. We use this index because it is the only one that covers the entire period of interest. We tested its convergent validity against the other measures and found a high correlation. 
national governance, measuring the movement from high government intervention and domestic market protectionism toward low government control of the economy and market aperture. The index ranges from 0 to 100, with higher values representing higher levels of structural reform.

We are also interested in analyzing how the type of firm (domestic state-owned, domestic private, or subsidiary of foreign firm) affects the relationship between structural reform and profitability. We measure the type of firm by its majority ownership following the classification of AmericaEconomía ${ }^{7}$. To test the influence of the type of firm on the relationship between structural reform and profitability (i.e., a moderation effect), we multiply the measure of structural reform by the indicator of domestic private firm, and by the indicator of subsidiary of foreign firm. These terms capture the impact of structural reform on profitability for each of these two types of firms relative to the base category, domestic state-owned firms ${ }^{8}$.

We control for other factors that may affect firm profitability. First, we control for the type of firm, because each type of firm has a baseline level of profitability regardless of the level of structural reform in the country. Second, we control for whether the firm has been privatized, because privatization reduces agency problems and improves profitability. As we indicated before, we do not discuss privatized firms in the theoretical development because they are not a type of firm ownership, but a change from one of the types to the others (i.e., from domestic state-owned to domestic private or subsidiaries of foreign firms); nevertheless, they are an important component of structural reform (Doh, Teegen, \& Mudambi, 2004; Ramamurti, 2000). Third, we control for firm size, because firms with larger resource pools may be in a better

\footnotetext{
$7 \quad$ AmericaEconomía classifies firms by majority ownership. One of the limitations of such a classification is that we cannot analyze the behavior of joint ventures or any other mixed-ownership firms, such as partially privatized firms (Gupta, 2005; Ramamurti, 2000). We cannot obtain ownership data from alternate sources because a large percentage of these firms are not publicly traded.

$8 \quad$ Only two variables are necessary to code a three category variable (domestic state-owned firm, domestic private firm, and subsidiary of foreign firm). The omitted category, domestic state-owned firm in this study, is the base category and the results are relative to that category (for an explanation see Frazier, Tix, \& Barron, 2004).
} 
position to achieve economies of scale and scope and higher levels of profitability. Fourth, we control for whether or not a firm is publicly-traded, because such firms are under more pressure from financial markets to generate high profitability; this pressure may increase with structural reform and the transformation of capital markets. Fifth, we control for whether or not a firm is part of a business group, because firms that belong to business groups may benefit from such associations and have higher profitability (Khanna \& Palepu, 2000). Sixth, we control for the industry, because different industries may show diverse overall levels of profitability (Caves, 1989). Seventh, we control for the level of development of the economy, because firms in wealthier countries may be able to achieve higher profitability. Eighth, we control for the growth of the economy because the business cycle is likely to affect firm profitability (Martin \& Parker, 1995). Ninth, we control for the openness of the economy, because exposure to international markets may affect firm profitability. Tenth, we control for other unobserved country-level factors with an indicator for each country because all firms in a country may be affected by country-wide factors. Eleventh, we control for year because year-specific influences and events may affect firm profitability. Finally, we control for other unobserved firm characteristics by using random effects models. We do not use fixed effects models because time-invariant variables of interest would drop out of the analysis. Moreover, the Hausman specification test indicates that the random effects model is efficient because the difference in coefficients of the fixed and random effects models is not systematic. The chi square of the difference in coefficients is 25.65 with a $p$ value of 0.53 .

\section{Method of Analysis}

To increase the robustness of the results, we use two methods of analysis, because each deals with a different data challenge. First, we use a cross-sectional time-series random effects 
generalized least squares (GLS) model with correction for panel-specific autocorrelation AR(1) and for heteroskedasticity. This model therefore addresses several issues that may be inherent in the error structure of panel data. Second, we use a three-level random coefficient (RCM) growth model. Due to the time-series and multilevel nature of the data, an RCM growth model may be the most appropriate method to test the relationships in question. The data are structured in three levels as observations for each year are nested within firms and firms are in turn nested within countries. RCM growth models have several advantages over General Linear Model (GLM) longitudinal designs. An RCM growth model allows for violations of sphericity in the error structure and is not affected by missing data, as long as it is missing at random ${ }^{9}$ (Ployhart, Holtz, \& Bliese, 2002). As such, it is a more robust method for testing this type of model. Following Bliese and Ployhart (2002), we employed an RCM Growth Model testing sequence to construct the model sequentially. We began step by step by building and testing the first level model, then the second level model, and finally the full three-level model. We obtained an Intraclass Correlation $[\mathrm{ICC}(1)]$ for our dependent variable (ROS) of 0.43 , suggesting a highly significant degree of nonindependence ${ }^{10}$. In other words, $43 \%$ of the variance in ROS can be explained by differences among firms. We calculated ICC(1) for firms nested within countries, and found it to be 0.39 . Hence, almost $40 \%$ of the variance in ROS can be explained by differences among firms for the different countries. One may therefore assume non-independence and start building an RCM model (Bliese \& Ployhart, 2002: 380).

\footnotetext{
9 To rule out the possibility of data not missing at random, we ran the models using zeros for all of the missing observations and attained very similar results, leading to equivalent support for the hypotheses.

10 The ICC on a dependent variable (DV) tells us how much of the variance of that variable can be explained by the higher level IVs (i.e. by group membership) (Bryk \& Raudenbush, 1992). Values above 0.10 indicate nonindependence of our DV and are thus desirable (Bliese \& Ployhart, 2002, p. 380). ICC(1) is calculated as the ratio of the between-group variance in ROS to the total variance in ROS and is equivalent to a one-way random effect ANOVA (analysis of variance) (Hofmann, Griffin, \& Gavin, 2000, p. 480).
} 
We follow the guidelines for testing models in the presence of categorical moderators presented in Frazier, Tix, and Barron $(2004)^{11}$. We grand mean center and standardize the continuous independent variables to reduce multicollinearity problems inherent in moderator models (Frazier, Tix, \& Barron, 2004; Hofman \& Gavin, 1998). We lag the data one year because structural reform in a given year is more likely to have an impact on firm profitability the following year. The specification of the general model we use is the following:

Profitability $_{i j k t}=\beta_{0}+\beta_{1} *$ Structural Reform St-1 $_{1}+\beta_{2} *$ Structural Reform $_{k t-1} *$ Domestic Private Firm $_{i j k t-1}+\beta_{3} *$ Structural Reform $k$ kt-1 $*$ Subsidiary of Foreign Firm Fikt-1 $_{1}+\beta_{4} *$ Domestic Private Firm $_{i j k t-1}+\beta_{5} *$ Subsidiary of Foreign Firm Fikt-1 $_{1}+\beta_{6} *$ Firm Sales $_{i j k t-1}+\beta_{7} *$ Publicly-traded $_{i j k t-1}$ $+\beta_{8} *$ Business Group $_{i j k t-1}+\beta_{9} *$ Privatized Firm $_{i j k t-1}+\beta_{10} *$ GDP per Capita kt- $1_{1}+\beta_{11} *$ Openness $_{k t-1}+\beta_{12} *$ GDP Growth $_{k t-1}+\beta_{j} *$ Industry $_{j t-1}+\beta_{k} *$ Country $_{k t-1}+\beta_{l} *$ Year $_{t-1}+\varepsilon$

To test Hypothesis 1, we do not include the interaction terms because we are interested in the general impact of structural reform on firm profitability. Without the interaction terms, $\beta_{1}$ captures the impact of structural reform on the profitability of all firms. Hypothesis 1 is supported if $\beta_{1}$ is positive and statistically significant. To test Hypothesis 2 , we use the full model and focus on the interaction terms. The results of multivariate studies with categorical moderator variables should be interpreted differently than other models because the results are conditional (Frazier, Tix, \& Barron, 2004: 121). With the interaction terms, $\beta_{1}$ captures the influence of structural reform on the profitability of domestic state-owned firms, which is the baseline firm type, $\beta_{2}$ captures the impact of structural reform on the profitability of domestic private firms relative to the impact on the profitability of domestic state-owned firms, and $\beta_{3}$

11 Frazier, Tix, and Barron (2004) caution that, in the presence of unequal error variance across groups (in this case across firm types) the results of multivariate analyses may be unreliable. Bartlett's test indicates homogeneous error variance, James' test and Alexander's test indicate the presence of a moderating effect, suggesting the data is suitable for multivariate analysis with a categorical moderator. 
captures the influence of structural reform on the profitability of subsidiaries of foreign firms relative to the influence on the profitability of domestic state-owned firms. Since Hypothesis 2 is expressed in relative terms, its support depends on the relative size of the coefficients. Therefore, Hypothesis 2 is supported when, at statistically significant levels, $\beta_{1}$ is positive, $\beta_{2}$ and $\beta_{3}$ are negative, their absolute values are smaller than $\beta_{1}$, and $\beta_{2}$ is larger than $\beta_{3}$.

\section{RESULTS}

Table 2 provides the summary statistics and correlation matrix. Structural reform takes values between 19.9 and 78.0 with a mean of 44.7. However, as we standardized it to avoid multicollinearity problems in the analysis of interactions, the descriptive statistics show a mean of 0 and standard deviation of 1 . Of the three types of firms in the sample, $13 \%$ are domestic state-owned firms, $54 \%$ are domestic private firms, and 33\% are subsidiaries of foreign firms. The average firm has US\$1.34 billion in sales and 9078 employees.

TABLE 2

Descriptive statistics and correlation matrix

\begin{tabular}{|c|c|c|c|c|c|c|c|c|c|c|c|c|c|}
\hline Variable & Mean & s.d. & 1 & 2 & 3 & 4 & 5 & 6 & 7 & 8 & 9 & 10 & 11 \\
\hline 1. Profitability & 3.67 & 19.63 & & & & & & & & & & & \\
\hline 2. Structural reform & 0.00 & 1.00 & -0.10 & & & & & & & & & & \\
\hline 3. State firm & 0.13 & 0.33 & 0.10 & -0.13 & & & & & & & & & \\
\hline 4. Private firm & 0.54 & 0.50 & 0.06 & -0.42 & 0.03 & & & & & & & & \\
\hline 5. Foreign firm & 0.33 & 0.47 & 0.01 & -0.27 & 0.06 & -0.77 & & & & & & & \\
\hline 6. Business group & 0.23 & 0.42 & 0.05 & -0.16 & 0.06 & 0.39 & -0.30 & & & & & & \\
\hline 7. Publicly traded & 0.40 & 0.49 & 0.06 & -0.14 & 0.14 & 0.29 & -0.21 & 0.22 & & & & & \\
\hline 8. Privatized firm & 0.09 & 0.18 & -0.04 & 0.27 & -0.05 & -0.10 & -0.09 & -0.04 & 0.11 & & & & \\
\hline 9. Sales & 0.00 & 1.00 & 0.04 & 0.21 & 0.04 & -0.12 & -0.02 & 0.08 & 0.03 & 0.02 & & & \\
\hline 10. GDP per capita & 0.00 & 1.00 & 0.04 & -0.19 & 0.67 & 0.05 & 0.09 & 0.05 & 0.07 & -0.04 & 0.10 & & \\
\hline 11. Openness & 0.00 & 1.00 & 0.11 & -0.06 & 0.08 & 0.04 & -0.01 & 0.03 & 0.05 & -0.02 & 0.02 & 0.10 & \\
\hline 12. GDP growth & 0.00 & 1.00 & 0.12 & -0.05 & 0.38 & 0.08 & -0.05 & 0.15 & 0.08 & -0.08 & 0.13 & 0.18 & 0.17 \\
\hline
\end{tabular}

$n=8500$. Correlations not in italics are significant at 0.05 (two-tailed test).

All continuous predictors are standardized (i.e. mean of 0 and standard deviation of 1 ).

Summary statistics for the 17 industry variables, 15 country variables, and 17 year variables not included for the sake of brevity. 
Table 3 presents the results of the analyses of the influence of structural reform on firm profitability and how this relationship varies across firm types. Models 1, 2, and 3 provide the results of the random-effects generalized least squares models with corrections for panel-specific autocorrelation and heteroskedasticity, and Models 4, 5, and 6 provide the results of the threelevel random coefficient growth models. Within each of these groups, the models are arranged incrementally as variables are added: the initial models (Models 1 and 4) include only the control variables, the next models (Models 2 and 5) add structural reform and serve to test Hypothesis 1, and the last models (Models 3 and 6) add the interaction between structural reform and the firm types and serve to test Hypothesis 2 .

TABLE 3

Results of the analyses of the impact of structural reform on firm profitability

\begin{tabular}{|c|c|c|c|c|c|c|c|c|c|c|}
\hline \multirow{3}{*}{$\begin{array}{l}\text { Variables }^{\mathrm{a}} \\
\text { Intercept }\end{array}$} & \multicolumn{4}{|c|}{$\begin{array}{l}\text { Time-series random effects generalized least squares (GLS) with } \\
\text { correction for heteroskedasticity and panel-specific autocorrelation }\end{array}$} & \multicolumn{6}{|c|}{$\begin{array}{l}\text { Three-level random coefficient (RCM) growth model } \\
\text { (also known as hierarchical linear HLM growth model) }\end{array}$} \\
\hline & Model 1 & \multicolumn{2}{|c|}{ Model 2} & Model 3 & \multicolumn{2}{|c|}{ Model 4} & \multicolumn{2}{|c|}{ Model 5} & \multicolumn{2}{|l|}{ Model 6} \\
\hline & $-8.19 * * *(1.66)$ & $-3.90 *$ & $(1.67)$ & $\begin{array}{ll}-2.37 \quad(1.55) \\
\end{array}$ & $-29.04 * *$ & $(9.30)$ & $-30.50 * *$ & $(9.18)$ & $-28.76^{* *}$ & $(9.02)$ \\
\hline Business group & $0.31 * * \quad(0.11)$ & 0.06 & $(0.09)$ & $0.52 * * *(0.09)$ & 0.76 & $(1.61)$ & 0.83 & $(1.55)$ & 0.85 & $(1.56)$ \\
\hline Publicly traded & $0.93 * * *(0.06)$ & $0.77 * * *$ & $(0.07)$ & $1.01 * * *(0.07)$ & 0.02 & $(1.10)$ & -0.10 & $(1.16)$ & -0.13 & (1.14) \\
\hline Privatized firm & $0.18 \quad(0.39)$ & 0.28 & $(0.37)$ & $0.44 * * *(0.12)$ & -0.12 & $(0.89)$ & -0.12 & $(0.89)$ & 0.53 & $(0.90)$ \\
\hline Sales & $0.36^{* *} \quad(0.13)$ & $0.51 * * *$ & $(0.11)$ & $0.56 * * *(0.11)$ & $0.69 *$ & $(0.31)$ & $0.74 *$ & $(0.31)$ & $0.67 *$ & $(0.31)$ \\
\hline GDP per capita & $-2.38 * * *(0.18)$ & $-2.70 * * *$ & $(0.17)$ & $-2.35 * * *(0.14)$ & $-2.65 * * *$ & $*(0.76)$ & $-3.44 * * *$ & $(0.81)$ & $-2.81 * * *$ & $(0.76)$ \\
\hline Openness & $1.23 * * *(0.03)$ & $1.33 * * *$ & $(0.02)$ & $1.21 * * *(0.03)$ & $1.28 * * *$ & $*(0.25)$ & $1.45 * * *$ & $(0.26)$ & $1.35 * * *$ & $(0.25)$ \\
\hline GDP growth & $3.10 * * *(0.13)$ & $4.19 * * *$ & $(0.11)$ & $4.10^{* * *}(0.11)$ & $2.82 * * *$ & $*(0.71)$ & $3.66 * * *$ & $(0.73)$ & $3.51 * * *$ & $(0.68)$ \\
\hline Industry control & Included & Included & & Included & Includec & & Included & & Included & \\
\hline Country control & Included & Included & & Included & Not requir & $\mathrm{red}^{\mathrm{b}}$ & Not require & & Not required & \\
\hline Year control & Included & Included & & Included & Include & & Included & & Included & \\
\hline Private firm & $9.46 * * *(0.35)$ & $9.61 * * *$ & $(0.33)$ & $7.85 * * *(0.29)$ & $9.68 * * *$ & $*(1.31)$ & $8.72 * * *$ & $(1.05)$ & $6.83 * * *$ & (1.13) \\
\hline Foreign firm & $8.11 * * *(0.35)$ & $8.18 * * *$ & $(0.33)$ & $6.63 * * *(0.30)$ & $7.80^{* * *}$ & $*(1.15)$ & $6.72 * * *$ & $(1.37)$ & $5.75 * * *$ & (1.13) \\
\hline Structural reform & --- & $1.94 * * *$ & $(0.11)$ & $6.02 * * *(0.21)$ & --- & & $2.33 * * *$ & $(0.67)$ & $6.42 * * *$ & $(1.03)$ \\
\hline Structural reform * private firm & --- & --- & & $-4.76^{* * *}(0.21)$ & --- & & --- & & $-4.31 * * *$ & $(1.00)$ \\
\hline Structural reform * foreign firm & --- & --- & & $-5.15 * * *(0.21)$ & --- & & --- & & $-5.88 * * *$ & (1.04) \\
\hline Log-Likelihood & -18457.59 & -18486.84 & & -18436.19 & -25272.00 & & -25265.25 & & -25249.05 & \\
\hline$\chi^{2}$ & 2477078 & $102000000 * * *$ & & $4577532 * * *$ & $42.60 * * *$ & & $6.75 * * *$ & & $16.20 * * *$ & \\
\hline $\mathrm{n}$ & 5810 & 5810 & & 5810 & 6063 & & 6063 & & 6063 & \\
\hline Groups (firms) & 869 & 869 & & 869 & 1122 & & 1122 & & 1122 & \\
\hline
\end{tabular}

\footnotetext{
${ }^{a}$ Base category for country, industry, and year are included in the models but their coefficients are not reported for the sake of parsimony.

${ }^{\mathrm{b}}$ The RCM models observations for each year as nested within firms and firms as nested within countries, so country control is unnecessary. The $\chi^{2}$ reported is a Wald $\chi^{2}$ test for models 1-3 and a log likelihood ratio $\chi^{2}$ test for models 4-6. ${ }^{\dagger} \mathrm{p}<0.10 ;{ }^{*} \mathrm{p}<0.05 ; * * \mathrm{p}<0.01 ; * * * \mathrm{p}<0.001$. Two-tailed.
}

The results support Hypothesis 1. In Models 2 and 5, the coefficient of structural reform is positive and statistically significant. In other words, firms in countries with higher levels of 
structural reform tend to have higher profitability, on average. Since the measure of structural reform is standardized, we need to interpret the magnitude of the coefficient as indicating that an increase of one standard deviation in structural reform, on the aggregate, increases firm profitability by 2.33 percentage points (Model 5). As a benchmark estimation, if in 2004 firms in Mexico were operating at the level of structural reform that firms in Chile do, then their return on sales would be, on average, 4.2 percentage points higher, all else being equal.

The results also support Hypothesis 2. In Models 3 and 6, at statistically significant levels, the coefficient of structural reform, which captures the influence of structural reform on the profitability of the baseline category of domestic state-owned firms, is positive; the coefficient of the interactions between structural reform and domestic private firms is negative, and its absolute value is smaller than the coefficient of structural reform; the coefficient of the interaction between structural reform and subsidiaries of foreign firms is negative, and its absolute value is smaller than the coefficient of structural reform; and the coefficient of the interaction between structural reform and domestic private firm is larger than the coefficient of the interaction between structural reform and subsidiary of foreign firm, with a Wald test of the differences between these two coefficients being statistically significant at the $\mathrm{p}<0.05$ level. In other words, these results suggest that, on average, structural reform tends to have the highest positive impact on the profitability of domestic state-owned firms, followed by domestic private firms, and then by subsidiaries of foreign firms. As an example of how to interpret the coefficients, the results of Model 6 show that, ceteris paribus, with each increase of a unit in the standardized measure of structural reform, domestic state-owned firms improve their return on sales by $6.42 \%$, domestic private firms improve their return on sales by $2.11 \%(6.42-4.31)$, and subsidiaries of foreign firms improve their return on sales by $0.54 \%(6.42-5.88)$. 


\section{Alternative Explanations and Robustness Tests ${ }^{12}$}

We ran several additional analyses, not presented here for the sake of brevity, to verify that the findings are not explained by other reasons and to corroborate the robustness of the results. The alternative explanations are not supported.

First, we used alternative measures and found that they yield similar results. We used the Structural Reform Index from Lora (2001) and the Index of Economic Freedom from the Fraser Institute (Gwartney et al., 2007) as alternative measures of structural reform. We used return on assets, $\mathrm{ROA}^{13}$, as the dependent variable instead of ROS. We used two indicators of firm type (subsidiary of foreign firm vs. domestic firm) instead of three. We ran the analyses with two subsamples of firms: manufacturing firms (NAICS 1-3) and service firms (NAICS 4-7). We controlled for firm size using measures of assets, equity, or labor in place of sales. We used GNI per capita instead of GDP per capita. The results of these analyses support the same conclusions.

Second, we checked that survival bias does not explain the results. Some firms drop out of the database of the 500 largest companies, not necessarily because they have gone bankrupt, but more likely because they have not grown enough relative to others to appear in the top 500 by sales. We took the extreme position of assuming that all the firms that disappeared from the analyses and do not reappear went bankrupt, and for each of these observations we attached a value of zero to ROS. We also ran the analyses solely on the firms that appear every year. Alternatively, we only included firms that appear three or more times during the period of analysis. None of these additional analyses alters the conclusions.

Third, we used other methods to analyze the data. We used regression with serial correlation correction, regression with panel-corrected standard errors, regression with

\footnotetext{
12 We thank the editor and the anonymous reviewers for suggesting some of these robustness tests.

13 Although the results of the models using ROA yield equivalent support than the findings using ROS, we do not present them because a significant number of observations do not have information on assets in the database.
} 
heteroskedasticity-consistent standard errors, and included a lagged dependent variable to control for serial correlation. These results are consistent with the conclusions of the paper.

Additionally, we analyzed whether firm type is endogenously determined and affects the findings. We used a two-stage instrumental variable approach. We ran the models with firm type as a function of sales, publicly-traded, and business group. We used the results of this analysis in a second equation where we ran firm profitability as a function of the interaction between structural reform and firm type and the other controls. This analysis yields similar conclusions.

Fourth, we analyzed whether changes in ownership affect the findings. First, we coded change in ownership as a bivariate variable, assigning 1 for any firm that changes its ownership in the period and 0 otherwise. Second, we coded each of the changes among firm types with their own indicators. Third, we excluded firms that change ownership during the period of analysis. Again, the analyses support the same conclusions.

Moreover, to ensure that the privatization of firms does not affect the results, we ran analyses with four mutually-exclusive categories of firms (privatized, state-owned, private, and foreign) and their interactions with structural reform. We found that structural reform has a positive and statistically significant impact on the profitability of privatized firms, that this impact is lower than the positive impact on the profitability of domestic state-owned firms, but higher than the positive impact on the profitability of domestic private firms, followed by that of the subsidiaries of foreign firms. The general conclusions of the study are still supported. As we indicated before, we did not discuss privatized firms in the theoretical development because they represent a change in ownership type (i.e., from state-owned to domestic private or subsidiaries of foreign firms), rather than a type of firm by majority ownership. Still, this is an interesting and novel finding that future research may explore in more detail. Privatized firms not only increase 
profitability as a result of the change in ownership (e.g., Boubakri, Cosset, \& Guedhami, 2005; D’Souza, Megginson, \& Nash, 2005), but also improve their profitability with structural reform more than other domestic private or subsidiaries of foreign firms do.

Fifth, we studied whether individual dimensions of structural reform have a differential influence on profitability across firm types. We analyzed the individual impact of each of the five dimensions of structural reform captured in the index of structural reform for which we have data over the period of analysis: trade reform, financial policy reform, foreign investment reform, tax reform, and privatization. Results of these partial analyses show, first, that trade reform, foreign investment reform, tax reform, and privatization have a positive impact on the profitability of developing country firms on the aggregate, while the impact of financial policy reform on profitability is not significant. Second, when analyzing the impact of the dimensions of structural reform across types of firms, we find that the dimensions have the highest positive impact on the profitability of domestic state-owned firms and a variable influence on the profitability of the other two types of firms. Specifically, the influence of privatization and financial policy reform on profitability is highest for domestic state-owned firms, followed by domestic private firms, and finally for subsidiaries of foreign firms. Moreover, the impact of trade reform and tax reform is highest for domestic state-owned firms, followed by subsidiaries of foreign firms and, finally, domestic private firms. Additionally, the impact of foreign investment reform is highest for domestic state-owned firms than for the other two types of firms, with the difference between subsidiaries of foreign firms and domestic private firms not being statistically significant. These are interesting findings that can be explored in more detail in future research. 
Sixth, we analyzed whether the timing and pace of structural reform affects the findings. A commonly-assumed expectation is that structural reform has a negative influence on firm profitability in the short-term but, as companies adapt to the changes, it has a positive influence in the long-term. We did not find evidence to support this assertion. We ran analyses with multiple time lags (two to seven year lags) and found that the results are in line with the ones presented (one year lag) in terms of signs and significance. We also ran models with the square of the indicator of structural reform to analyze how the influence of structural reform changes over time. We found that structural reform has a positive influence on firm profitability, but at a decreasing rate, indicating that the main benefit from structural reform occurs at the beginning and diminishes over time. This is an interesting finding. Finally, we analyzed whether the pace with which structural reform is introduced (i.e., gradually or quickly) affects profitability. We followed Vermeulen and Barkema (2002) and used the kurtosis of structural reform over the period as the indicator of pace. We found that pace of structural reform has no statistically significant impact on profitability and that the findings do not change.

Finally, we analyzed whether the time of the creation of the firm affects the findings. Firms that were created during the import substitution period may have been established with technologies and operations designed for the prevailing conditions in the countries. As structural reform is implemented, these firms may suffer because they cannot adapt to the new conditions. We therefore ran two additional models: one in which we control for the age of the firm, and another in which we control for whether or not a firm was established after the end of the period of import substitution. We used firm directories (Brewin, Porter, Romiti, \& Tapster 2008; Gale Group, 2007; Green, 2003; Mergent Online, 2007) and the firms' official websites to obtain the year of establishment, and Sachs and Warner (1995) to determine the end of the period of import 
substitution for each country. The results show that the coefficients of age or of the indicator for whether or not a firm was established after the end of the period of import substitution are not statistically significant, while the other coefficients remain in line with the ones described.

\section{CONCLUSIONS}

This paper studies the impact of structural reform on firm profitability in developing countries. This question is part of an important debate on the benefits of globalization. The paper extends agency theory by arguing that structural reform improves external monitoring mechanisms that help ameliorate managerial misbehavior, thus reducing agency costs and improving firm profitability. It also argues that structural reform has a differential positive impact on the profitability of domestic state-owed, domestic private and subsidiaries of foreign firms, because their specific agency problems are impacted differently. Thus, it proposes and finds support for the idea that, contrary to critics of globalization, the main beneficiaries of structural reform are domestic state-owned firms, followed by domestic private firms and then by subsidiaries of foreign firms.

The paper contributes to two literatures, one theoretical and another thematic. First, the paper contributes to agency theory by introducing a novel source of changes in agency costs. Traditional agency studies have discussed how agency costs change with changes in ownership (e.g., Berger et al., 2005). Here we argue that agency costs change with changes in the institutional environment. As such, the paper not only discusses a novel source of changes in agency costs, but also provides agency theory with links to its external environment. The paper also illustrates how agency theory can be used to explain not only the relationship between managers and shareholders that most researchers are familiar with (e.g., Jensen \& Meckling, 
1976), but also other agency relationships, such as those between citizens and politicians, among multiple shareholders and managers, and between headquarters and subsidiary managers.

Second, the paper contributes to the debate on the benefits of globalization (e.g., Bhagwati, 2004; Guillen, 2001; Henisz, Zelner, \& Guillen, 2005; Rodrik, 2006) by explaining and providing evidence of which firms benefit from one aspect of globalization, structural reform. Critics of globalization contend that structural reform only benefits foreign firms and, therefore, developing countries should refrain from it (e.g., Mander \& Goldsmith, 1996). The findings support the contrarian idea that domestic firms, especially state-owned ones, are the main beneficiaries of structural reform. Hence, policymakers in developing countries may consider and defend structural reform as a means of strengthening the domestic firms that serve as the backbone of their economy. The arguments illustrate how management-level theory, agency theory in our case, can help inform policymakers by explaining the mechanisms that link institutional changes to firm profitability.

This line of study has some limitations that can be addressed in future research. First, the paper analyzes structural reform as an aggregate concept. Structural reform has multiple components and has been implemented differently over time. Although we ran some analyses as robustness checks, future studies can explain in more detail how each of the dimensions of structural reform affects agency costs and firm profitability, and how the timing and pace of the implementation of structural reform affects firms. Second, the paper focuses on developing countries, where state-owned, private and foreign firms coexisted before and throughout structural reform. Whereas the general argument that structural reform improves external monitoring and firm profitability is likely to apply to firms in transition economies, the specific discussion of who is the main beneficiary is likely to differ because private firms in transition 
economies did not exist before the transition, but were created as a result, and thus are likely to behave differently. Future research can analyze how the transition process influenced the agency problems and profitability of different types of firms to better understand the impact of institutional change on firms. Third, we test the ideas on a sample of firms in Latin America, a region that followed an import substitution model of economic development before embarking on a path of structural reform. Other countries in Africa (e.g., Egypt, Ghana) and Asia (e.g., India, Turkey) followed this process. Thus, the arguments presented are likely to explain the behavior of firms there as well, but future research can verify this. Fourth, we analyze large firms. Future research can analyze the behavior of small firms which, although not having the same ability as large firms to adapt to structural reform, may suffer fewer agency problems. Fifth, we study the impact of structural reform on firm profitability. Although we argue and show that structural reform tends to be positive for firm profitability, structural reform affects many other economic and social aspects that future research may address in detail. Sixth, we do not directly test the mediating mechanisms that link structural reform to firm profitability because of data limitations. Future research can measure and test these mechanisms, analyzing which one has a large impact on profitability improvements.

In sum, in this paper we explain and show that structural reform has a positive influence on firm profitability, especially for domestic firms. This line of research not only counters critics of globalization and serves to guide public policy regarding structural reform, but also opens new avenues of research on the impact of institutional change on firm behavior and performance. 


\section{REFERENCES}

Amann, E., \& Nixson, F. I. 1999. Globalisation and the Brazilian steel industry: 1988-97. Journal of Development Studies, 35: 59-88.

AmericaEconomía. Various years. Las Mayores Empresas de America Latina. Special Issue.

Anderson, R. C. \& Reeb, D. M. 2003. Founding-family ownership, corporate diversification, and firm leverage. Journal of Law \& Economics, 46: 653-680.

Andersson, U., Forsgren, M., \& Holm, U. 2007. Balancing subsidiary influence in the federative MNC: a business network view. Journal of International Business Studies, 38: 802-818.

Aoki, M. 1990. Toward an economic model of the Japanese firm. Journal of Economic Literature, 28: 1-27.

Appiah-Adu, K. 1999. The impact of economic reform on business performance: a study of foreign and domestic firms in Ghana. International Business Review, 8: 463-486.

Barkema, H. G. \& Gomez-Mejia, L. R. 1998. Managerial Compensation and Firm Performance: A General Research Framework. Academy of Management Journal, 41: 135-145.

Becht, M., Bolton, P., \& Roell, A. 2003. Corporate governance and control. In G. M. Constantinides \& M. Harris \& R. Stulz (Eds.), Handbook of the Economics of Finance, Vol. 21: 1-109. Amsterdam: Elsevier.

Berger, A., Clarke, G., Cull, R., Klapper, L.,\& Udell, G., 2005. Corporate governance and bank performance: A joint analysis of the static, selection, and dynamic effects of domestic, foreign, and state ownership. Working paper \#3632. Washington DC: World Bank.

Bhagwati, J. 2004. In Defense of Globalization. New York: Oxford University Press.

Birkinshaw, J. 2001. Strategy and management in MNE subsidiaries. In A. M. Rugman \& T. L. Brewer (Eds.), The Oxford Handbook of International Business: 380-401. New York: Oxford University Press.

Bliese, P. D., \& Ployhart, R. E. 2002. Growth modeling using random coefficient models: Model building, testing, and illustration. Organizational Research Methods, 5: 362-387.

Blomstrom, M. \& Kokko, A. 1998. Multinational corporations and spillovers. Journal of Economic Surveys, 12: 247-277.

Blomstrom, M. 1986. Foreign investment and productive efficiency: the case of Mexico. Journal of Industrial Economics, 35: 97-110.

Boardman A. E., \& Vining, A. R. 1989. Ownership and performance in competitive environments: A comparison of the performance of private, mixed, and state-owned enterprises. Journal of Law and Economics, 32: 1-33.

Bonardi J. P. 2004. Global and political strategies in deregulated industries: The asymmetric behaviors of former monopolies. Strategic Management Journal, 25: 101-120.

Bonardi, J. P., Hillman, A. J., \& Keim, G. D. 2005. The attractiveness of political markets: implications for firm strategy. Academy of Management Review, 30: 397-413.

Booth, L., Aivazian, V., Demirguc-Kunt, A., \& Maksimovic, V. 2001. Capital structures in developing countries. Journal of Finance, 56: 87-130.

Borenstein, A., \& D'Atri, D. Como operan los cazadores de empresas (How do hunters of firm operate) Clarin, December 8, 6-8.

Boubakri, N., Cosset, J.-C., \& Guedhami, O. 2005. Liberalization, corporate governance and the performance of privatized firms in developing countries. Journal of Corporate Finance, 11: 767-790. 
Brewin, H., Porter, H., Romiti, L., \& Tapster, C. (Eds.) 2008. Major Companies of Latin America and the Caribbean 2008. London: Graham \& Whiteside.

Bruton, H. J. 1998. A reconsideration of import substitution. Journal of Economic Literature, 36: 903-936.

Bryk, A. S., \& Raudenbush, S. W. 1992. Hierarchical Linear Models: Applications and Data Analysis Methods, Newbury Park, N. J.: Sage.

Camuffo, A., Furlan, A., \& Rettore, E. 2007. Risk sharing in supplier relations: an agency model for the Italian air-conditioning industry. Strategic Management Journal, 28: 1257-1266.

Caves, R. E. 1989. International differences in industrial organization. In R. Schmalensee \& R. D. Willig (Eds.), Handbook of Industrial Organization. Amsterdam: Elsevier.

Chemi, L., \& Figueroa, J. 1995. Llegan los salvadores de las PYMES (The saviours of small and medium enterprises arrive). Clarin, December 3: 12-13.

Chung, C. C. \& Beamish, P. W. 2005. The impact of institutional reforms on characteristics and survival of foreign subsidiaries in emerging economies. Journal of Management Studies, 42: 35-62.

Cigler, A. J., \& Loomis, B. A. (eds). 2006. Interest Group Politics, $7^{\text {th }}$ ed. Washington DC: Congressional Quarterly Press.

Claessens, S., Djankov, S., \& Lang, L. 2000. The separation of ownership and control in East Asian corporations. Journal of Financial Economics, 58: 81-112.

Colburn, F. D. \& Sánchez, F. F. 2000. Empresarios Centroamericanos y Apertura Económica. San José, Costa Rica: Editorial Universitaria Centroamericana.

Correa, R. 1996. Para el grup Exxel, crear valor es el mejor negocio (For the Exxel group, value creation is the best business) La Nación, December 8: 2.1.- 2.6

Coughlan, A. T. \& Schmidt, R. M. 1985. Executive compensation, management turnover, and firm performance: An empirical investigation. Journal of Accounting and Economics, 7: 43-66.

Cuervo, A., \& Villalonga, B. 2000. Explaining the variance in the performance effect of privatization. Academy of Management Review, 25: 581-590.

Cuervo-Cazurra, A. \& Un, C. A. 2004. Firm-specific and non-firm-specific sources of advantages in international competition. In Ariño, A., Ghemawat, P. \& Ricart, J. (eds.) Creating and Appropriating Value from Global Strategy. New York: Palgrave MacMillan.

Cuervo-Cazurra, A. 2007. Sequence of value-added activities in the internationalization of developing country MNEs. Journal of International Management, 13: 258-277.

Cuervo-Cazurra, A. 2008. The internationalization of developing country MNEs: The case of Multilatinas. Journal of International Management, 14: 138-154.

Cuervo-Cazurra, A., \& Genc, M. 2008. Converting disadvantages into advantages: Developing country MNEs in the least developed countries. Journal of International Business Studies (Forthcoming)

Cuervo-Cazurra, A., Maloney, M., \& Manrakhan, S. 2007. Causes of the difficulties in internationalization. Journal of International Business Studies, 38: 709-725.

Daily, C. M., Dalton, D. R., \& Cannella Jr., A. A. 2003. Corporate governance: Decades of dialogue and data. Academy of Management Review, 28(3): 371-382.

Demsetz, H. 1973. Industry structure, market rivalry, and public policy. Journal of Law \& Economics, 16: 1-9. 
Dewenter, K. L., \& Malatesta, P. H. 2001. State-owned and privately owned firms: An empirical analysis of profitability, leverage, and labor intensity. American Economic Review, 91: 320-334.

Dharwadkar, R., George, G., \& Brandes, P. 2000. Privatization in emerging economies: An agency theory perspective. Academy of Management Review, 25: 650-669.

Dixit, A., Grossman, G. M., \& Helpman, E. 1997. Common agency and coordination: General theory and application to government policy making. Journal of Political Economy, 105: 752-769.

Djankov, S., La Porta, R., Lopez-de-Silanes, F., \& Shleifer, A. 2002. The regulation of entry, Quarterly Journal of Economics, 117: 1-37.

Doh, J. P., Teegen, H., \& Mudambi, R. 2004. Balancing private and state ownership in emerging markets' telecommunications infrastructure: country, industry and firm influences. Journal of International Business Studies, 35: 233-250.

Doz, Y., \& Prahalad, C. K. 1984. Patterns of strategic control within multinational corporations. Journal of International Business Studies, 15: 55-72.

D'souza, J., \& Megginson, W. L. 1999. The financial and operating performance of privatized firms during the 1990s. Journal of Finance 54: 1397-1438.

D'Souza, J., Megginson, W. L., \& Nash, R. 2005. Effect of institutional and firm-specific characteristics on post-privatization performance: Evidence from developed countries. Journal of Corporate Finance, 11: 747-766.

ECLAC. 2007. Panorama Social de America Latina 2007. Santiago de Chile: Economic Commission for Latin America and the Caribbean, United Nations.

ECLAC. Various years. Foreign Investment in Latin America and the Caribbean. Santiago de Chile: Economic Commission for Latin America and the Caribbean, United Nations.

Eisenhardt, K. M. 1989. Agency Theory: An assessment and review. Academy of Management Review, 14: 57-74.

Elahee, M. N., \& Vaidya, S. P., 2001. Coverage of Latin American business and management issues in cross-cultural research: An analysis of JIBS and MIR 1987-1997. International Journal of Organization Theory \& Behaviour, 4: 21-31.

Escaith, H., \& Morley, S. 2000. The Impact of Structural Reforms on Growth in Latin America and the Caribbean: An Empirical Estimation. Santiago de Chile: ECLAC, United Nations.

Eslava, M., Haltiwanger, J., Kugler, A., \& Kugler, M. 2004. The effects of structural reforms on productivity and profitability enhancing reallocation: Evidence from Colombia. Journal of Development Economics, 75: 333-371.

Estenssoro, M. E.. 1992. Perez Companc: El nuevo numero 1 (Perez Companc: The new number 1). Mercado, March: 22-29

Fama, E. F. \& Jensen, M. C. 1983. Separation of ownership and control. Journal of Law and Economics, 26: 301-325.

Fama, E. F. 1980. Agency problems and the theory of the firm. Journal of Political Economy, 88: 288-307.

Fisman, R. 2001. Estimating the value of political connections. American Economic Review, 91: 1095-1102.

Fraga, E. 2004. Latin America since the 1990s: Rising from the sickbed? Journal of Economic Perspectives, 18: 89-106. 
Frazier, P. A., Tix, A. P., \& Barron, K. E. 2004. Testing moderator and mediator effects in counseling psychology research. Journal of Counseling Psychology, 51: 115-134.

Fretz, D. 2000. El precio del silencio. AmericaEconomia, 188, July 27: 55-57.

Friedman, M. 1962. Capitalism and Freedom. Chicago: University of Chicago Press.

Gale Group. 2007. Business and Company Resource Center. Gale Group. www.galegroup.com/BusinessRC/. Accessed February and March 2008.

Galindo, A., Micco, A., \& Panizza, U. 2006. Two decades of financial reforms. In E. Lora (Ed.), The State of State Reform in Latin America. Palo Alto, CA: Stanford University Press.

García-Canal, E., \& Guillén, M. F. 2008. Risk and the strategy of foreign location choice in regulated industries. Strategic Management Journal, DOI: 10.1002/smj.692.

Geringer J. M., Tallman, S., \& Olsen, D. M. 2000. Product and international diversification among Japanese multinational firms. Strategic Management Journal, 21: 51-80.

Gersbach, H., \& Schmutzler, A. 2007. Does Globalization Create Superstars? C.E.P.R. Discussion Papers, CEPR Discussion Papers: 6222.

Ghemawat, P., \& Khanna, T. 1998. The nature of diversified business groups: A research design and two case studies. Journal of Industrial Economics, 46: 35-61.

Green, S. (Ed.) 2003. Major Companies of Latin America and the Caribbean 2003. London: Graham \& Whiteside

Grosse, R. 2001. International business in Latin America. In Rugman, A.M., \& Brewer, T.L. (Eds.), The Oxford Handbook of International Business, New York: Oxford University Press.

Guilléen, M. F. 2000. Business groups in emerging economies: A resource-based view. Academy of Management Journal, 43: 362-380.

Guilléen, M. F. 2001. Is globalization civilizing, destructive or feeble? A critique of six key debates in the social science literature. Annual Review of Sociology, 27: 235-260.

Guillén, M. 2005. The Rise of Spanish Multinationals: European Business in the Global Economy. Cambridge University Press: Cambridge.

Gupta, N. 2005. Partial privatization and firm performance. Journal of Finance, 60: 987-1015.

Gwartney, J., Lawson, R., \& Easterly, W. 2007. Economic Freedom of the World: 2006 Annual Report, Vancouver: The Fraser Institute.

Harris, M., \& Raviv, A. 1991. A theory of capital structure. Journal of Finance, 46: 297-355

Hart, O. D. 1983. The market mechanism as an incentive scheme. Bell Journal of Economics, 14: 366-382.

Hay, D. A. 2001. The post-1990 Brazilian trade liberalisation and the performance of large manufacturing firms: Productivity, market share and profits. Economic Journal, 111: 620641.

Henisz, W. J. 2000. The institutional environment for multinational investment, Journal of Law, Economics and Organization, 16: 334-364.

Henisz, W. J., Zelner, B. A., \& Guillen, M. F. 2005. The worldwide diffusion of market-oriented infrastructure reform, 1977-1999. American Sociological Review, 70: 871-897.

Herrera, A. M. \& Lora, E. 2005. Why so small? Explaining the size of firms in Latin America. World Economy, 28: 1005-1028.

Hofmann, D. A. \& Gavin, M. B. 1998. Centering decisions in hierarchical linear models: Theoretical and methodological implications for organizational science. Journal of Management, 23: 623-641. 
Hofmann, D. A., Griffin, M. A., \& Gavin, M. B. 2000. The application of hierarchical linear modeling to organizational research. In K. Klein \& S. W. J. Kozlowski (Eds.), Multilevel theory, research, and methods in organizations: Foundations, extensions, and new directions: 467-511. San Francisco, CA: Jossey-Bass.

Holmstrom, B. R. \& Tirole, J. 1989. The theory of the firm. In R. Schmalensee \& R. D. Willig (Eds.), Handbook of Industrial Organization, 1: 61-134. Amsterdam: Elsevier.

Hoskisson, R. E., Eden, L., Lau, C. M., \& Wright, M. 2000. Strategy in emerging economies. Academy of Management Journal, 43: 249-267.

Jensen, M. C. \& Murphy, K. J. 1990. Performance pay and top-management incentives. Journal of Political Economy, 98: 225-264.

Jensen, M. C. 1993. The modern industrial revolution, exit, and the failure of internal control systems. Journal of Finance, 48: 831-880.

Jensen, M. C., \& Meckling, W. H. 1976. Theory of the firm: managerial behavior, agency costs and ownership structure. Journal of Financial Economics, 3: 305-360.

Kane, T., Holmes, K. R., \& O'Grady, M. A. 2007. 2007 Index of Economic Freedom: The Link Between Economic Opportunity and Prosperity. Washington: Heritage Foundation.

Katrak, H. 2000. Economic liberalization and the vintages of machinery imports in developing countries: an empirical test for India's imports from the United Kingdom. Oxford Development Studies, 28: 309-322.

Katrak, H. 2002. Does economic liberalisation endanger indigenous technological developments? An analysis of the Indian experience. Research Policy, 31: 19-30.

Katz, J. 2004. Market-oriented reforms, globalization and the recent transformation of Latin American innovation systems. Oxford Development Studies, 32: 375-387.

Keynes, J. M. 1936. The General Theory of Employment, Interest and Money. London: Macmillan.

Khanna, T. \& Palepu, K. 1997. Why focused strategies may be wrong for emerging markets. Harvard Business Review, 75: 41-51.

Khanna, T. \& Palepu, K. 2000. The future of business groups in emerging markets: Long-run evidence from Chile. Academy of Management Journal, 43: 268-285.

Khanna, T., Kogan, J., \& Palepu, K. 2006. Globalization and similarities in corporate governance: A cross-country analysis. Review of Economics \& Statistics, 88: 69-90.

Kim, B. \& Prescott, J. E. 2005. Deregulatory forms, variations in the speed of governance adaptation, and firm performance. Academy of Management Review, 30: 414-425.

Kornai, J. 1990. Vision and Reality: Market and State. New York: Routledge.

Krueger, A. 1974. The political economy of the rent-seeking society. American Economic Review, 64: 291-303.

Kuczynski, P. P. 2003. The financial system. In Kuczynski, P. P., \& Williamson, J., After the Washington Consensus. Restarting Growth and Reform in Latin America. Washington, D.C.: Institute for International Economics.

Kuczynski, P. P., \& Williamson, J., 2003. After the Washington Consensus. Restarting Growth and Reform in Latin America. Washington, D.C.: Institute for International Economics.

La Porta, R., Lopez-de-Silanes, F., \& Shleifer, A. 1999. Corporate ownership around the world. Journal of Finance, 54: 471-517.

La Porta, R., Lopez-de-Silanes, F., Shleifer, A., \& Vishny, R. W. 1998. Law and finance, Journal of Political Economy, 106: 1113-1155. 
Laffont, J. J. \& Tirole, J. 1990. The politics of government decision making: regulatory institutions. Journal of Law, Economics, and Organization, 6: 1-31.

Lall, S. 1983. The New Multinationalss. Wiley: New York.

Lassar, W. M. \& Kerr, J. L. 1996. Strategy and control in supplier-distributor relationships: An agency perspective. Strategic Management Journal, 17: 613-632.

Lawson, C. 1994. The theory of state-owned enterprises in market economies. Journal of Economic Surveys, 8: 284-309.

Lora, E. 2001. Structural Reforms in Latin America: What Has Been Reformed and How to Measure It. Working Paper No. 466. Washington: Inter-American Development Bank.

Lora, E., Panizza, U., \& Quispe-Agnoli, M. 2004. Reform fatigue: Symptoms, reasons, implications. Federal Reserve Bank of Atlanta Economic Review (2): 1-28.

Mander, J. \& Goldsmith, E. (eds.) 1996. The Case against the Global Economy and for a Turn toward the Local. San Francisco: Sierra Club Books.

Martin, S. \& Parker, D. 1995. Privatization and economic performance throughout the UK business cycle. Managerial \& Decision Economics, 16: 225-237.

Marx, K., \& Engels, F. 1848 (1906). Manifesto of the Communist Party. (Kerr \& Co: Chicago).

Mata, J. \& Portugal, P. 2004. Patterns of entry, post-entry growth and survival. Small Business Economics, 22: 283-298.

Megginson, W. L., \& Netter, J. M. 2001. From state to market: a survey of empirical studies on privatization. Journal of Economic Literature, 39: 321-89.

Megginson, W., Nash, R., \& Randenborgh, M., 1994. The financial and operating performance of newly privatized firms: An international empirical analysis. Journal of Finance, 49: 403-452.

Mercado. 1991. Alpargatas, camino a Wall Street. (Alpargatas, on the path to Wall Street. Mercado, July: 19-20

Mergent Online. 2007. Mergent. www.mergentonline.com. Accessed February and March 2008.

Meyer, K. E. 2001. International business research on transition economies. In A. M. Rugman \& T. L. Brewer (Eds.), The Oxford Handbook of International Business: 716-759. New York: Oxford University Press.

Micco, A., Panizza, U., \& Yanez, M. 2007. Bank ownership and performance. Does politics matter? Journal of Banking and Finance, 31: 219-241.

Milgrom, P. \& Roberts, J. 1990. The economics of modern manufacturing: Technology, strategy and organization. American Economic Review, 80: 511-528.

Milgrom, P. \& Roberts, J. 1992. Economics, Organization, and Management. Englewood Cliffs, NJ: Prentice Hall.

Mitton, T. 2006. Stock market liberalization and operating performance at the firm level. Journal of Financial Economics, 81: 625-647.

Moguillansky, G. \& Bielschowsky, R. 2000. Inversión y reformas económicas en América Latina. Santiago de Chile: ECLAC, United Nations.

Morck, R., Wolfenzon, D., \& Yeung, B. 2005. Corporate governance, economic entrenchment, and growth. Journal of Economic Literature, 43: 655-720.

Morley, S. A., Machado, R., \& Pettinato, S. 1999. Indexes of Structural Reform in Latin America. Serie Reformas Economicas 12. Santiago de Chile: ECLAC, United Nations.

Mudambi, R. \& Navarra, P. 2004. Is knowledge power? Knowledge flows, subsidiary power and rent-seeking within MNCs. Journal of International Business Studies, 35: 385-406. 
North, D. C. 1990. Institutions, Institutional Change and Economic Performance. Cambridge: Cambridge University Press.

Ocampo, J. A. 2004. Latin America's growth and equity frustrations during structural reforms. Journal of Economic Perspectives, 18: 67-88.

Okoroafo, S. C. 1993. Firm performance in a liberalized environment: Empirical evidence from a developing country. Journal of Business Research, 28: 175-189.

Olson, M. 1971. The Logic of Collective Action. Cambridge, MA: Harvard University Press.

Palepu, K. 1985. Diversification strategy, profit performance and the entropy measure. Strategic Management Journal, 6: 239-255.

Peng, M. W. \& Heath, P. S. 1996. The growth of the firm in planned economies in transition: Institutions, organizations, and strategic choice. Academy Management Review,21: 492528.

Phan, P. H. \& Hill, C. W. L. 1995. Organizational restructuring and economic performance in leveraged buyouts: An ex-post study. Academy of Management Journal, 38: 704-739.

Ployhart, R. E., Holtz, B. C., \& Bliese, P. D. 2002. Longitudinal data analysis: Applications of random coefficient modeling to leadership research. Leadership Quarterly, 13: 455-486.

Prebisch, R. 1950. The Economic Development of Latin America and its Principal Problems. New York: United Nations.

Prendergast, C. 1999. The provision of incentives in firms. Journal of Economic Literature, 37: 7-63.

Ramamurti, R. 2000. A multilevel model of privatization in emerging economies. Academy of Management Review, 25: 525-550.

Reuer, J. J. \& Ragozzino, R. 2006. Agency hazards and alliance portfolios. Strategic Management Journal, 27: 27-43.

Rimuli, V. 1994. Negocios Familiares. Estar en paz para poder arriesgar (Family business: Be in peace to be able to risk) Mercado, October: 151-154.

Rodrik, D. 2006. Goodbye Washington consensus, hello Washington confusion? A review of the World Bank's economic growth in the 1990s: Learning from a decade of reform. Journal of Economic Literature, 44: 973-987.

Roland, G., \& Sekkat, K. 2000. Managerial career concerns, privatization and restructuring in Transition Economies. European Economic Review, 44: 1857-1872.

Ross, S. A. 1973. The economic theory of agency: The principal's problem. American Economic Review, 63: 134-139.

Roth, K. \& O'Donnell, S. 1996. Foreign subsidiary compensation strategy: An agency theory perspective. Academy of Management Journal, 39: 678-703.

Sachs, J. D. \& Warner, A. 1995. Economic reform and the process of global integration. Brookings Papers on Economic Activity, 1995: 1-118.

Sahay, R., \& Goyal, R. 2006. Volatility and Growth in Latin America: An Episodic Approach. IMF Working Paper 06-287. Washington, D.C.: IMF.

Salim, R. A. 2003. Economic liberalization and productivity growth: further evidence from Bangladesh. Oxford Development Studies, 31: 85-98.

Scharfstein, D. S., \& Stein, J. C. 2000. The dark side of internal capital markets: Divisional rentseeking and inefficient investment. Journal of Finance, 55: 2537-64.

Schneyer, J. 2005. La excepción a la regla. AmericaEconomía, 280-281, 18 August: 66-67.

Shleifer, A., \& Vishny, R. 1994. Politicians and firms. Quarterly Journal of Economics, 109: 995-1025. 
Shleifer, A., \& Vishny, R. 1997. A survey of corporate governance. Journal of Finance, 52: 737-783.

Skidmore, T. E., \& Smith, P. H. 2005. Modern Latin America. New York: Oxford University Press.

Smith, A. 1776. An Inquiry into the Nature and Causes of the Wealth of Nations. Chicago, IL: University of Chicago Press.

Spiller, P. T. 1990. Politicians, interest groups, and regulators: A multiple-principals agency theory of regulation, or "let them be bribed". Journal of Law and Economics, 33: 65-101.

Stiglitz, J. E. 2003. Globalization and its Discontents. New York: Norton.

Stok, G. 2000. El elefante emprende vuelo. AmericaEconomía, 188, 27 July: 40-41.

Tallman, S. B. \& Yip, G. S. 2001. Strategy and the multinational enterprise. In A. M. Rugman \& T. L. Brewer (Eds.), The Oxford Handbook of International Business: 317-348. New York: Oxford University Press.

Thomas, D. E., Eden, L., Hitt, M. A., \& Miller, S. R. 2007. Experience of emerging market firms: The role of cognitive bias in developed market entry and survival. Management International Review, 47: 845-867.

Vera H., \& Stok, G. 2000. El juego de los españoles. AmericaEconomía, 188, 27 July: 49-53.

Vermeulen, F., \& Barkema, H. 2002. Pace, rhythm, and scope: process dependence in building a profitable multinational corporation. Strategic Management Journal, 23: 637-653.

Vickers, J., \& Yarrow, G. 1988. Privatization. Cambridge, MA: MIT Press.

Vogelsang, I. 1990. Public Enterprise in Monopolistic and Oligopolistic Industries. Chur: New York.

von Hayek, F. 1944. The Road to Serfdom. Chicago: Chicago University Press.

Walsh, J. P., \& Seward, J. K. 1990. On the efficiency of internal and external corporate control mechanisms. Academy of Management Review, 15: 421-458.

Williamson, J. 1990. Latin American Adjustment: How Much Has Happened? Washington: Institute for International Economics.

Williamson, J. 2000. What Should the World Bank Think About the Washington Consensus? World Bank Research Observer, 15(2), August.

Williamson, J. 2004. The strange history of the Washington Consensus. Journal of Post Keynesian Economics, 27: 195-206.

Winston, C. 1993. Economic deregulation: Days of reckoning for microeconomists. Journal of Economic Literature, 31: 1263-1289.

World Bank. 2008. World Development Indicators Online. http://devdata.worldbank.org/dataonline/ Accessed January 4.

Wright, M., Filatotchev, I., Hoskisson, R. E.,\& Peng, M. W. 2005. Strategy research in emerging economies: Challenging the conventional wisdom. Journal of Management Studies,42:133.

Wright, P., Kroll, M., Lado, A., \& van Ness, B. 2002. The structure of ownership and corporate acquisition strategies. Strategic Management Journal, 23: 41-53.

Yergin, D. \& Stanislaw, J. 1998. The Commanding Heights. New York: Touchstone.

Zaheer, S. 1995. Overcoming the liability of foreignness. The Academy of Management Journal, 38: 341-363.

Zhara, S. A., Ireland, R. D., Gutiérrez, I., \& Hitt, M. A. 2000. Privatization and entrepreneurial transformation. Emerging issues and a future research agenda. Academy of Management Review, 25: 509-524. 


\section{DAVIDSON INSTITUTE WORKING PAPER SERIES - Most Recent Papers}

The entire Working Paper Series may be downloaded free of charge at: www.wdi.umich.edu

CURRENT AS OF 11/17/08

\begin{tabular}{|c|c|c|}
\hline Publication & Authors & Date \\
\hline $\begin{array}{l}\text { No. 940: Structural Reform And Firm Profitability In Developing } \\
\text { Countries }\end{array}$ & $\begin{array}{l}\text { Alvaro Cuervo-Cazurra \& Luis } \\
\text { Alfonso Dau }\end{array}$ & July 2008 \\
\hline $\begin{array}{l}\text { No. 939: Does Timing Of Elections Instigate Riots? } \\
\text { A Subnational Study Of } 16 \text { Indian States, } 1958 \text { - } 2004\end{array}$ & Krishna Chaitanya Vadlamannati & Oct 2008 \\
\hline $\begin{array}{l}\text { No. 938: Price Setting And Market Structure: An Empirical Analysis Of } \\
\text { Micro Data }\end{array}$ & Fabrizio Coricelli \& Roman Horvath & Sept 2008 \\
\hline $\begin{array}{l}\text { No. 937: Inflation Differentials in EU New Member States: An Empirical } \\
\text { Evidence }\end{array}$ & Roman Horvath \& Kamila Koprnicka & Oct 2008 \\
\hline $\begin{array}{l}\text { No. 936: Market Reforms and Growth in Post-socialist Economies: } \\
\text { Evidence from Panel Cointegration and Equilibrium Correction Model }\end{array}$ & Igor Pelipas and Alexander Chubrik & Sept 2008 \\
\hline $\begin{array}{l}\text { No. 935: Derivatives trading and the volume-volatility link in the Indian } \\
\text { Stock Market }\end{array}$ & $\begin{array}{l}\text { S. Bhaumiky, M. Karanasosy and } \\
\text { A. Kartsaklas }\end{array}$ & April 2008 \\
\hline $\begin{array}{l}\text { No. 934: Yuan Real Exchange Rate Undervaluation, 1997-2006. How } \\
\text { Much, How Often? Not Much, Not Often }\end{array}$ & $\begin{array}{l}\text { Jeff Chen, Wende Deng \& David } \\
\text { Kemme }\end{array}$ & Aug 2008 \\
\hline $\begin{array}{l}\text { No. 933: How Important Are Foreign Shocks in Small Open Economy? } \\
\text { The Case of Slovakia }\end{array}$ & $\begin{array}{l}\text { Roman Horváth and Marek } \\
\text { Rusnák }\end{array}$ & Sept 2008 \\
\hline $\begin{array}{l}\text { No. 932: Estimating Poverty for Indigenous Groups in Chile } \\
\text { by Matching Census and Survey Data }\end{array}$ & $\begin{array}{l}\text { Claudio A. Agostini, Philip H. } \\
\text { Brown, and Andrei Roman }\end{array}$ & Aug 2008 \\
\hline $\begin{array}{l}\text { No. 931: Is There Electoral Cycles In Globalization Process? Evidence } \\
\text { From } 78 \text { Democratic Countries, } 1975 \text { - } 2006\end{array}$ & Krishna Chaitanya Vadlamannati & Sept 2008 \\
\hline No. 930: Lobbying, Corruption \& Other Banes & $\begin{array}{l}\text { Nauro Campos \& Francesco } \\
\text { Giovannoni }\end{array}$ & Sept 2008 \\
\hline $\begin{array}{l}\text { No. 929: Do Elections Slow Down Economic Globalization Process In } \\
\text { India? It's Politics Stupid! }\end{array}$ & Krishna C Vadlamannati & Aug 2008 \\
\hline $\begin{array}{l}\text { No. 928: Impact Of Institutional Quality On Human Rights Abuses } \\
\text { In Transition Economies }\end{array}$ & $\begin{array}{l}\text { Krishna C Vadlamannati \& Artur } \\
\text { Tamazian }\end{array}$ & July 2008 \\
\hline $\begin{array}{l}\text { No. 927: Do Choice \& Speed Of Reforms Matter For } \\
\text { Human Rights During Transition? }\end{array}$ & Krishna Chaitanya Vadlamannati & July 2008 \\
\hline $\begin{array}{l}\text { No. 926: Socioeconomic, Institutional \& Political Determinants Of } \\
\text { Human Rights Abuses: A Subnational Study Of India, } 1993 \text { - } 2002\end{array}$ & Krishna Chaitanya Vadlamannati & July 2008 \\
\hline $\begin{array}{l}\text { No. 925: Does the Entry Mode of Foreign Banks Matter for Bank } \\
\text { Efficiency? Evidence from the Czech Republic, Hungary, and } \\
\text { Poland }\end{array}$ & $\begin{array}{l}\text { Ngoc-Anh Vo Thi \& Dev } \\
\text { Vencappa }\end{array}$ & July 2008 \\
\hline No. 924: Impact Of Economic Reforms On Poverty - Indian Experience & Krishna Chaitanya Vadlamannati & July 2008 \\
\hline $\begin{array}{l}\text { No. 923: India \& South Asia - Indian Economic Reforms \& Direct } \\
\text { Foreign Investments: How Much Difference Do They Make To } \\
\text { Neighbors? }\end{array}$ & Krishna Chaitanya Vadlamannati & July 2008 \\
\hline $\begin{array}{l}\text { No. 922: The Effects of Monetary Policy in the Czech Republic: } \\
\text { An Empirical Study }\end{array}$ & $\begin{array}{l}\text { Magdalena Morgese Borys and } \\
\text { Roman Horváth }\end{array}$ & May 2008 \\
\hline $\begin{array}{l}\text { No. 921: Goods Market Integration in Russia during the Economic } \\
\text { Upturn }\end{array}$ & Konstantin Gluschenko & May 2008 \\
\hline $\begin{array}{l}\text { No. 920: Labour Market Matching Efficiency In The Czech Republic } \\
\text { Transition }\end{array}$ & Pablo de Pedraza & April 2008 \\
\hline $\begin{array}{l}\text { No. 919: The Emerging Aversion to Inequality: Evidence from Poland } \\
\text { 1992-2005 }\end{array}$ & Irena Grosfeld and Claudia Senik & April 2008 \\
\hline $\begin{array}{l}\text { No. 918: Exploring The Relationship Between Military Spending \& } \\
\text { Income Inequality In South Asia }\end{array}$ & Krishna Chaitanya Vadlamannati & Feb 2008 \\
\hline
\end{tabular}

